\title{
IN-SITU CONTAINMENT AND STABILIZATION OF BURIED WASTE - ANNUAL REPORT FY 1994
}

\author{
M. L. Allan and L. E. Kukacka
}

October 1994

\section{Energy Efficency and Conservation Division}

Department of Applied Science

Brookhaven National Laboratory

Upton, New York 11973

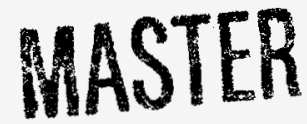

DISTREATION OF INW DOCUMAENT IS UNLMMTED

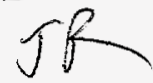

This work was performed under the auspices of the U.S. Department of Energy Washington, D.C. Under Contract No. DE-AC02-76CH00016 


\section{DISCLAIMER}

This report was prepared as an account of work sponsored by an agency of the United States Government. Neither the United states Government nor any agency thereof, nor any of their employees, nor any of their contractors, subcontractors, or their employees makes any warranty, express or implied, or assumes any legal liability or responsibility for the accuracy, completeness, or usefulness of any information, apparatus, product or process disclosed, or represents that its use would not infringe privately owned rights. Reference herein to any specific commercial product, process, or service by trade name, trademark, manufacturer, or otherwise, does not necessarily constitute or imply its endorsement, recommendation, or favoring by the United states Government or any agency thereof. The views and opinions of authors expressed herein do not necessarily state or reflect those of the United states Government or any agency, contractor, or subcontractor thereof. 


\section{DISCLAIMER}

Portions of this document may be illegible in electronic image products. Images are produced from the best available original document. 
LIST OF TABLES........................... iv

LIST OF FIGURES $\ldots \ldots \ldots \ldots \ldots \ldots \ldots \ldots \ldots \ldots \ldots \ldots \ldots \ldots \ldots \ldots$

SUMMARY ................................. viii

1.0 Introduction. .......................... 1

2.0 In-situ stabilization of Chromium contaminated soil.... 2

2.1 Introduction........................... 2

2.2 Experimental Work........................ 3

2.2 .1 Materials.......................... 3

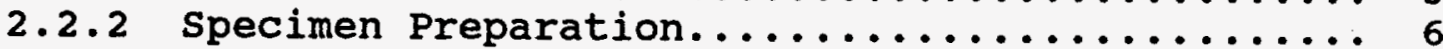

2.2 .3 curing........................... 6

2.2 .4 viscosity.......................... 7

2.2 .5 Specific Gravity.................... 7

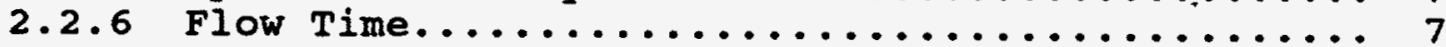

2.2 .7 Leach Tests......................... 7

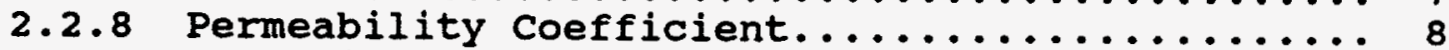

2.2 .9 Unconfined Compressive strength............ 8

2.2.10 wet-Dry Durability Tests................. 9

2.3 Results and Discussion...................... 9

2.3.1 Unhardened Grout Properties................ 9

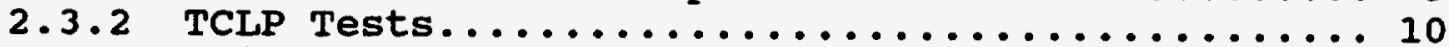

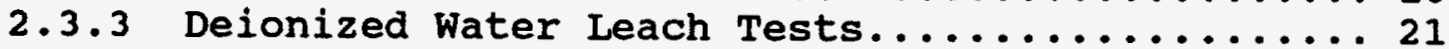

2.3 .4 Permeability Coefficient................... 22

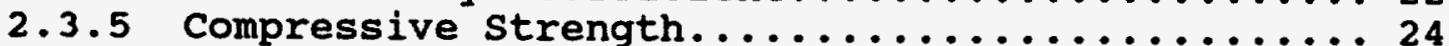

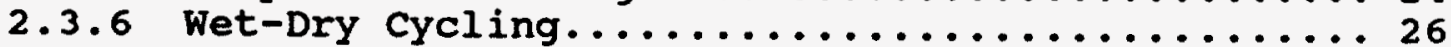

2.3 .7 General Discussion..................... 28

2.3.8 Recommendations for Future Work on In-situ Stabilization...................... 28

3.0 In-situ containment of stabilized chromium Plume..... 30

3.1 Introduction............................. 30

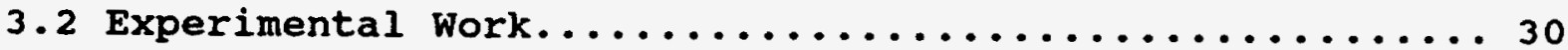

3.2 .1 Materials.......................... 30

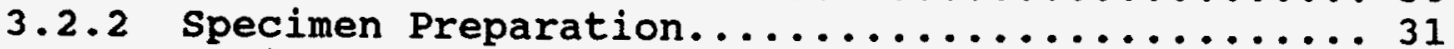

3.2 .3 curing............................ 32

3.2 .4 Unhardened Grout Properties............... 32

3.2 .5 Permeability Coefficient................. 32

3.2 .6 Unconfined Compressive strength............. 33

3.2 .7 Chromium Diffusion Tests................. 33 
3.2 .8 Permeation Grouting.................. 35

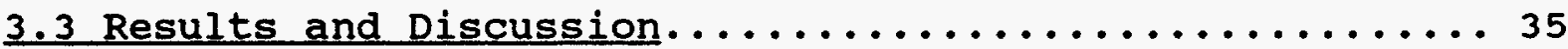

3.3.1 Permeability Coefficient of Slag Modified Soil

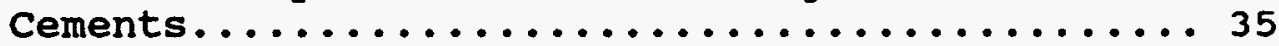

3.3.2 Permeability Coefficient of Soil cured Grout

Before and After Drying................. 40

3.3.3 Permeability Coefficient of soil Cured soil

3.3 .4 Cements Before and After Drying............ 42

3.3 .5 Compressive strength................... 44

3.3 .6 Chromium Diffusion.................... 44

3.3.7 Permeation Grouting cores................ 47

3.3.8 General Discussion of In-Situ Containment of Chromium Plume......................447

3.3.9 Recommendations for Future Work on In-Situ Containment of Chromium Plumes............48

4.0 Jet Grouting Field Trials................... 49

5.0 In-Situ Immobilization of Tritium Plume.......... 53

6.0 In-situ Containment of Tritium Plume........... 54

6.1 Introduction........................... 54

6.2 Experimental work.......................... 54

6.2 .1 Materials.......................... 54

6.2 .2 Specimen Preparation................... 55

6.2 .3 curing............................ 56

6.2 .4 Unhardened Grout Properties................ 56

6.2 .5 Permeability Coefficient................. 56

6.2 .6 Unconfined Compressive strength............ 56

6.2 .7 Wet-Dry Cycle Tests.................... 56

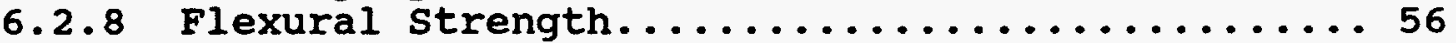

6.2 .9 Tritium Diffusion Tests................ 57

6.3 Results and Discussion..................... 57

6.3.1 Unhardened Grout Properties................ 57

6.3 .2 Permeability Coefficient................. 58

6.3 .3 Compressive strength.................... 60

6.3 .4 Flexural strength.................... 60

6.3 .5 Tritium Diffusion..................... 63

7.0 site visit. ........................... 66

8.0 Technology Transfer...................... 67

8.1 Patents................................ 67 
8.2 publications.......................... 67

8.3 Publications in Press.......................667

8.4 Publications under Review....................67

8.5 Conferences.............................67

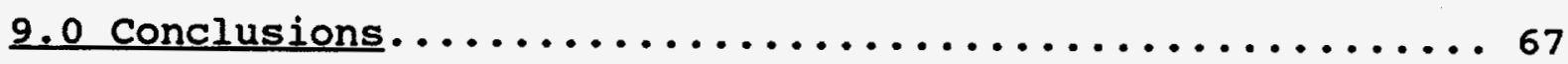

10.0 References.............................68 


\section{LIST OF TABLES}

Page

Table 1. Mix Proportions of Grouts.................. 4

Table 2. Mix Proportions of Treated Soils............. 5

Table 3. Rheological Properties of Unhardened Grouts....... 9

Table 4. Specific Gravities of Unhardened Grouts......... 10

Table 5. TCLP Results for Landfill Soils Treated with $40 \%$ Slag/60q Cement Mix..................... 19

Table 6. Results for Deionized water Leach Tests........ 22

Table 7. 28 Day Wet Cured Compressive Strength of Stabilized soil............................... 26

Table 8. 84 Day Wet Cured Compressive Strength of Stabilized soil............................... 26

Table 9. Residual Compressive Strength of Stabilized soil.. 28

Table 10. Mix Proportions of CWL Barrier Grouts.......... 31

Table 11. Mix Proportions of CWL Soil Cement Barriers..... 31

Table 12. Mix Proportions of Microfine Cement Grout...... 35

Table 13. Properties of Unhardened Microfine Cement Grout.. 35

Table 14. Permeability Coefficients of Slag Modified Soil Cements........................... 36

Table 15. Permeability Coefficients of wet cured slag Modified Soil Cements After Wet-Dry Cycles...... 36

Table 16. Permeability coefficients of Plain and Fibre Reinforced Grout Before and After Wet-Dry Cycles. 40

Table 17. Permeability Coefficients of Plain and Fibre Reinforced Soil Cements Before and After Wet-Dry Cycles............................4 42

Table 18. Compressive strength of Slag Modified Soil Cements..............................444

Table 19. Mix Proportions of Grouts for Jet Grouting Field Trials........................... 51

Table 20. Properties of Unhardened Grouts Prepared in Laboratory........................ 51 
Table 21. Jet Grouting Parameters and Grout Properties.... 52

Table 22. Mix Proportions of Grouts for MWL Barriers...... 55

Table 23. Mix Proportions of MWL Soil Cement Barriers..... 55

Table 24. Unhardened Grout Properties for MWL Barriers.... 58

Table 25. Permeability Coefficients Before and After Wet-Dry Cycles for MWL Barrier Grouts ......... 58

Table 26. Compressive strength of MWL Barrier Grouts..... 60

Table 27. Flexural strength of MWL Barrier Grouts.......663

Table 28. Intrinsic Diffusion Coefficients for Tritium.... 64 


\section{LI8T OF FIGURES}

Page

Figure 1. TCLP results for $200 \mathrm{ppm}$ Cr(III) soil treated with slag modified grouts............... 11

Figure 2. TCLP leachate $\mathrm{pH}$ for $200 \mathrm{ppm}$ Cr(III) soil treated with slag modified grouts................ 13

Figure 3. TCLP results for $200 \mathrm{ppm} \mathrm{Cr(VI)} \mathrm{soil} \mathrm{treated}$ with slag modified grouts at soil/cementitious

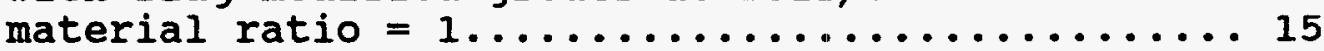

Figure 4. TCLP results for $200 \mathrm{ppm} \mathrm{Cr(VI)} \mathrm{soil} \mathrm{treated}$ with slag modified grouts at soil/cementitious material ratio $=2 \ldots \ldots \ldots \ldots \ldots \ldots \ldots \ldots \ldots$

Figure 5. TCLP results for $200 \mathrm{ppm} C r$ (VI) soil treated with slag modified grouts at soil/cementitious

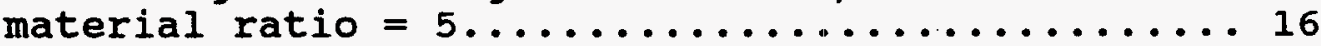

Figure 6. TCLP leachate $\mathrm{pH}$ for $200 \mathrm{ppm} \operatorname{Cr}(\mathrm{VI})$ soil treated with slag modified grouts................. 17

Figure 7. TCLP results for $200 \mathrm{ppm} \mathrm{Cr(VI)} \mathrm{soil} \mathrm{treated}$ with $40 \% \mathrm{slag} / 60$ cement grout before and after exposure to air for 7 months.............. 18

Figure 8. TCLP results for $200 \mathrm{ppm}$ Cr(VI) soil treated with $80 \%$ slag/20\% cement grout before and after exposure to air for 7 months............... 20

Figure 9. Permeability coefficient versus soil/cementitious material ratio for $200 \mathrm{ppm}$ Cr(III) soil treated with slag modified grouts... 23

Figure 10. Compressive strength versus soil/cementitious material ratio for $200 \mathrm{ppm}$ Cr(III) soil treated with slag modified grouts................ 25

Figure 11. Schematic diagram of diffusion cell used for chromium and tritium diffusion experiments..... 34

Figure 12. Permeability coefficient of slag modified soil cements after 28 days wet curing........... 37

Figure 13. Permeability coefficient of slag modified soil cements after 84 days soil curing.......... 38

Figure 14. Permeability coefficient of wet cured slag modified soil cements before and after 12 wet-dry cycles. 
Figure 15. Effect of $0.2 \%$ Fibrillated (0.2F) and $0.2 \%$ Monofilament Fibres (0.2MF) on Permeability Coefficient of soil cured Grout Before and After

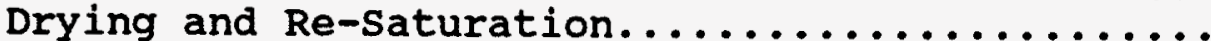

Figure 16. Effect of $0.2 \%$ Fibrillated $(0.2 \mathrm{~F})$ and $0.2 \%$ Monofilament Fibres (0.2MF) on Permeability Coefficient of Soil cured Soil Cement Before and After Drying and Re-saturation...............

Figure 17. Relationship Between Permeability Coefficient and Confining Pressure for Cracked soil cement with $0.2 \%$ Monofilament Fibres (47S2 $0.2 \mathrm{MF}) \ldots 45$

Figure 18. Compressive strength versus soil/cementitious material ratio for slag modified soil cements... 46

Figure 19. Permeability coefficients of wet cured grouts before and after 12 wet-dry cycles.......... 59

Figure 20. Compressive strength of grouts after 28 and 84 days wet curing....................6 61

Figure 21. Flexural strength of grouts after 28 days wet curing..........................6 62

Figure 22. Tritium diffusion versus time for grouts and soil cements.....................665 


\section{SUMMARY}

Research on advanced grouting materials for in-situ stabilization and containment of buried hazardous waste that was initiated in FY 92 continued in FY 94. The three main areas of focus for FY 94 were in-situ stabilization of chromium contaminated soil, subsurface containment barriers for chromium plumes and subsurface containment barriers for tritiated water plumes.

Grouts containing blast furnace slag as a partial replacement for cement were studied for stabilization of trivalent and hexavalent chromium contaminated soil. The levels of slag, soil/grout ratios and water/cementitious material ratios were varied in order to determine the best combination of properties. Soil stabilized with grout was subjected to a variety of tests, including EPA Toxicity Characteristic Leaching Procedure, ANS 16.1 deionized water leaching, strength and permeability. Treatment of contaminated soil with slag modified grout resulted in a strong, low permeability product that passed EPA leaching tests. Both trivalent or hexavalent chromium could be stabilized. Landfill soil samples with $6110 \mathrm{ppm} C r$ were also successfully treated. It was determined that addition of slag to grout was necessary for reduction of hexavalent to trivalent chromium, followed by immobilization as chromium hydroxide. A slag content greater than $20 \%$ by weight of total cementitious materials was necessary for greatest leach resistance. This is compatible with Type Is cement which is preblended with 25 to $75 \%$ slag. The great advantage of using a slag modified grout for in-situ stabilization of chromium contaminated soil is that either Cr(III) or the more mobile and toxic Cr(VI) can be treated since no pre-reduction of $\mathrm{Cr}$ (VI) is needed. This simplifies and reduces the time and costs associated with $\mathrm{Cr}(\mathrm{VI})$ remediation immensely.

Investigation of resistance to permeable cracking of cementitious subsurface containment barriers continued. Addition of slag to grouts for containment barriers was initiated and the grout properties were characterized. Soil cements containing slag were also developed and characterized. Jet grouting field trials using plain and slag modified grouts were conducted at an uncontaminated site at SNL.

Grout and soil cements were investigated as potential barriers for soil contaminated with tritiated water. Diffusion coefficients were measured and determined to be of the order of $10^{-11}$ to $10^{-10} \mathrm{~m}^{2} / \mathrm{s}$. These values are similar to those previously reported for grout and concrete. It is evident that grout and soil cement barriers do not afford permanent containment of tritium. At the relatively low level of tritium activity in the MWL plume it is marginal whether placement of a cementitious barrier for tritium containment would be sufficiently beneficial. 


\subsection{INTRODUCTION}

The ongoing objective of this work is to develop, demonstrate and implement advanced grouting materials for in-situ installation of subsurface containment barriers and for in-situ stabilization of chromium contaminated soils. The work is conducted as part of the Mixed Waste Landfill Integrated Demonstration (MWLID) headquartered at Sandia National Laboratory (SNL). The two landfills of specific interest are the Chemical Waste Landfill (CWL) and the Mixed Waste Landfill (MWL), both located at SNL. The work on grouting materials was initiated in FY 92 and the previous accomplishments are documented in the FY 92 and FY 93 annual reports.

The work is comprised of two subtasks: (1) In-Situ Barriers and (2) In-situ stabilization of contaminated soils. The main environmental concern at the CWL is a chromium plume resulting from disposal of chromic acid and chromic sulphuric acid into unlined pits. This program has investigated means of in-situ stabilization of chromium contaminated soil and placement of containment barriers around the CWL. The MWL contains a plume of tritiated water. Insitu immobilization of tritiated water with cementitious grouts was not considered to be a method with a high probability of success and was not pursued. This is discussed further in section 5.0. containment barriers for the tritium plume were investigated.

FY 92 work examined stabilization of chromium contaminated soil and determined that reduction of hexavalent chromium was necessary before treatment with either Portland cement grout or calcium hydroxide. Polymer, cementitious and polymer modified cementitious barrier grouts for the CWL were investigated in FY 92 . The grouts were formulated for use as either monolithic (i.e. grout only) barriers or for in-situ mixing with soil to produce soil cement barriers. Additives for significantly improving the cured properties of cementitious grouts and grout treated soils over conventional materials were identified. Polymer grouts were considered to not be cost effective for the site studied since the properties of interest were not significantly improved over cementitious grouts, yet the raw material cost was high. In addition, cementitious grouts had other practical benefits such as easy clean up, handling and environmental safety, reaction control and worker familiarity.

In FY 93 work concentrated on optimization and characterization of CWL barrier grout and soil cement formulations. Mixes were tested for properties such as permeability, strength, wet-dry durability, shrinkage, resistance to shrinkage cracking, leach resistance, freeze-thaw durability and flow behaviour. Fibres were investigated as a means of improving crack resistance. While fibres improved resistance to restrained shrinkage cracking, the effects on permeability and wet-dry durability were variable. Fibre reinforcement studies were continued in FY 94 and will be discussed in this report. Some problems with obtaining uniform mixing of fibres were encountered, and field tests would be 
necessary to completely evaluate the practicality of their use in grouts.

FY 94 work focused on stabilization of chromium contaminated soil with blast furnace slag modified grouts to bypass the stage of pre-reduction of $\mathrm{Cr}$ (VI), barriers for tritiated water containment at the MWL, continued study of barriers for the CWL, and jet grouting field trials for CWL barriers at an uncontaminated site at SNL. Cores from the FY 93 permeation grouting field trails were also tested in FY 94.

\subsection{IN-8ITU BTABILIZATION OF CHROMIUM CONTAMINATED SOIL}

\subsection{Introduction}

Between 1962 and 1985 solutions of chromic and chromic sulphuric acid were dumped into unlined pits at the CWL. Since then, migration of chromium to a depth of $23 \mathrm{~m}$ has been detected. The total chromium concentrations in the soil vary with depth and the typical value is approximately $200 \mathrm{ppm}$. Concentrations up to 6000 ppm exist in some locations. The chromium is present in both the trivalent and hexavalent oxidation states.

Trivalent chromium can be stabilized by addition of basic reagents, such as cement or calcium hydroxide, to precipitate chromium hydroxide. In addition to formation of $\mathrm{Cr}(\mathrm{OH})_{3}$, Mollah et al. (1992) and Ivey et al. (1990) suggested that Cr(III) may substitute for $\mathrm{Si}$ in the calcium silicate hydrate phase of cement. Ivey et al. (1990) also postulated that Cr(III) substituted for Al and $\mathrm{Fe}$ in calcium aluminate hydrates and calcium aluminoferrite hydrates. Kindess et al. (1994) did not find evidence of incorporation of $\mathrm{Cr}$ (III) into calcium silicate hydrate, but did find that $C r$ (III) could substitute for $A l$ in calcium aluminate hydrates.

The more mobile and toxic hexavalent state of chromium requires pretreatment by reduction to $\operatorname{Cr}$ (III) before stabilization as the hydroxide (Connor, 1990). Leaching experiments performed by Zamorani et al. (1988) have demonstrated that $\operatorname{Cr}$ (VI) is not permanently immobilized by addition of Portland cement. Reduction agents for $\mathrm{Cr}$ (VI) include ferrous sulphate, bisulphites and sulphides (Connor, 1990). Potential drawbacks of these agents for the landfill remediation include the necessity for $\mathrm{pH}$ adjustment prior to mixing with ferrous sulphate and generation of $\mathrm{SO}_{2}$ with bisulphites. Other problems with soil pretreatment by solutions are that reduction may be slow and incomplete due to previous diffusion of chromium into soil particles (Connor, 1990). The potential safety and environmental hazards of sulphide or bisulphite treatment and the EPA regulations regarding $\mathrm{H}_{2} S$ production should also be regarded. Any unreacted Cr(VI) will remain mobile and this is cause for concern.

In FY 92, treatability studies of soil contaminated with 
either trivalent or hexavalent chromium were conducted (Allan, Kukacka and Heiser, 1992). Soil spiked with 1000 ppm Cr(III) was successfully stabilized by a pumpable, superplasticized Portland cement grout. Reduction of $\mathrm{Cr}$ (VI) with $\mathrm{Fe}^{2+}$ solutions and stabilization with lime was also investigated and found to be successful.

Work in FY 94 examined means of overcoming problems and costs associated with a two stage treatment process for $\mathrm{Cr}$ (VI). The objective was to combine the reduction and stabilization steps. Reduction of $\operatorname{Cr}$ (VI) to $\mathrm{Cr}$ (III) and subsequent stabilization has been observed for cements containing ground granulated blast furnace slag (Kindness et al., 1994; Langton, 1988, Langton and Wong, 1991). This is attributed to the low redox potential of sulphur bearing slag modified cements as compared to ordinary Portland cements (Macphee and Glasser, 1993). Langton (1988) demonstrated significantly lower total chromium concentrations in EPA Toxicity Characteristic Leaching Procedure (TCLP) tests when blast furnace slag was added to saltstone formulations. Analysis of pore fluid expressed from cement pastes spiked with $5000 \mathrm{ppm}$ Cr(VI) showed that ordinary Portland cement had $71 \mathrm{ppm}$ total $\mathrm{Cr}$ of which $70 \mathrm{ppm}$ was $\mathrm{Cr}$ (VI) whereas a blend with $10 \%$ ordinary Portland cement and $90 \%$ slag had $<0.01$ ppm total $\mathrm{Cr}$ (Kindness et al., 1994).

Use of cement grouts containing blast furnace slag for remediation of chromium contaminated soil was investigated because of the potential for simultaneous reduction and stabilization of hexavalent chromium. Elimination of a separate pretreatment stage would simplify and expedite environmental restoration. Furthermore, in cases where the chromium exists as a combination Cr(III) and $\operatorname{Cr}(V I)$, slag modified cements can be used to treat both. Grouts can be used with in-situ placement techniques such as jet grouting or soil mixing, thereby making remediation safer and more efficient than methods which require soil excavation.

In this study, grouts containing 0 to $80 \%$ blast furnace slag by weight of cement plus slag were mixed with soils contaminated with trivalent and hexavalent chromium and the cured soil cement was subjected to leach tests. The ratio of soil to grout was varied to determine the amount of soil that could be treated satisfactorily. Permeability, wet-dry durability and strength tests were also performed to characterize the treated soil.

\subsection{Experimental Nork}

\section{$\underline{2.2 .1}$ Materials}

The grouts consisted of Type I cement, ground granulated blast furnace slag, water, bentonite and superplasticizer. The slag was ASTM C 989 Grade 100 and was supplied by Koch Minerals. The bentonite was sodium montmorillonite. Sodium naphthalene sulphonate formaldehyde superplasticizer with $42 \%$ solids by weight was used to reduce the water/cementitious material (cement plus 
slag) ratio (w/C). Superplasticizer was added at a rate of 20 ml/kg cementitious material. Silica fume modified grout was also investigated. The silica fume was supplied by Norcem Concrete products. The grout was added to soil at soil/cementitious material ratios (s/C) by weight of 1,2 and 5 . Additional mixing water was required at the higher soil/cementitious material ratios. Soil from an uncontaminated site near the CWL was used. The soil was dried prior to use so that moisture content was constant.

The mix proportions of the grouts and treated soils are given in Tables 1 and 2 respectively. slag was used at cement replacement levels of $0,20,40,60$ and $80 \%$ by weight of total cementitious materials (cement plus slag) and the corresponding $M i x$ Numbers are $47,80,74,75$ and 78 . Silica fume was used at a replacement level of $5 \%$ by weight of total cementitious material. The last number in the $\mathrm{mix}$ code refers to the s/c value $(1-5)$. The silica fume modified $\mathrm{mix}(58-5)$ was used at a s/c value of 5 . The proportions may require alteration for field application depending on the type of placement equipment used and the soil conditions.

\section{Table 1. Mix Proportions of Grouts}

\begin{tabular}{|c|c|c|c|c|c|c|}
\hline $\begin{array}{c}\text { Mix } \\
\text { No. }\end{array}$ & $\begin{array}{c}\text { Cement } \\
\left(\mathrm{kg} / \mathrm{m}^{3}\right)\end{array}$ & $\begin{array}{c}\text { Slag } \\
\left(\mathrm{kg} / \mathrm{m}^{3}\right)\end{array}$ & $\begin{array}{c}\text { Silica } \\
\text { Fume } \\
\left(\mathrm{kg} / \mathrm{m}^{3}\right)\end{array}$ & $\begin{array}{c}\text { Water } \\
\left(\mathrm{kg} / \mathrm{m}^{3}\right)\end{array}$ & $\begin{array}{c}\text { Bentonite } \\
\left(\mathrm{kg} / \mathrm{m}^{3}\right)\end{array}$ & $\begin{array}{c}\mathrm{sP} \\
\left(1 / \mathrm{m}^{3}\right)\end{array}$ \\
\hline $47-1$ & 1221 & 0 & 0 & 586 & 11.1 & 24.4 \\
\hline $47-2$ & 948 & 0 & 0 & 679 & 13.3 & 19.0 \\
\hline $47-5$ & 571 & 0 & 0 & 799 & 15.4 & 11.4 \\
\hline $58-5$ & 534 & 0 & 28 & 788 & 15.2 & 11.2 \\
\hline $80-1$ & 971 & 243 & 0 & 583 & 11.0 & 24.3 \\
\hline $80-2$ & 751 & 188 & 0 & 675 & 13.2 & 18.8 \\
\hline $80-5$ & 453 & 113 & 0 & 794 & 15.3 & 11.3 \\
\hline $74-1$ & 722 & 481 & 0 & 577 & 10.9 & 24.1 \\
\hline $74-2$ & 556 & 370 & 0 & 667 & 13.0 & 18.5 \\
\hline $74-5$ & 338 & 225 & 0 & 788 & 15.2 & 11.3 \\
\hline $75-1$ & 478 & 718 & 0 & 574 & 10.9 & 23.9 \\
\hline $75-2$ & 368 & 553 & 0 & 663 & 13.0 & 18.5 \\
\hline $75-5$ & 225 & 338 & 0 & 788 & 15.2 & 11.3 \\
\hline $78-1$ & 236 & 945 & 0 & 567 & 10.7 & 23.6 \\
\hline $78-2$ & 184 & 733 & 0 & 659 & 12.9 & 18.3 \\
\hline $78-5$ & 111 & 447 & 0 & 782 & 15.1 & 11.2 \\
\hline
\end{tabular}


N.B. $S P=$ superplasticizer

Table 2. Mix Proportions of Treated soils

\begin{tabular}{||c|c|c|c|c|c|c|}
\hline Mix No. & $\begin{array}{c}\text { Cement } \\
\left(\mathrm{kg} / \mathrm{m}^{3}\right)\end{array}$ & $\begin{array}{c}\text { Slag } \\
\left(\mathrm{kg} / \mathrm{m}^{3}\right)\end{array}$ & $\begin{array}{c}\text { Water } \\
\left(\mathrm{kg} / \mathrm{m}^{3}\right)\end{array}$ & $\begin{array}{c}\text { Bentonite } \\
\left(\mathrm{kg} / \mathrm{m}^{3}\right)\end{array}$ & $\begin{array}{c}\mathrm{SP} \\
\left(1 / \mathrm{m}^{3}\right)\end{array}$ & $\begin{array}{c}\text { Soil } \\
\left(\mathrm{kg} / \mathrm{m}^{3}\right)\end{array}$ \\
\hline $47 \mathrm{~S} 1$ & 816 & 0 & 391 & 6.5 & 16.3 & 816 \\
\hline $47 S 2$ & 537 & 0 & 388 & 7.7 & 10.7 & 1075 \\
\hline $47 S 5$ & 268 & 0 & 376 & 7.4 & 5.4 & 1342 \\
\hline $80 S 1$ & 654 & 162 & 391 & 6.5 & 16.3 & 816 \\
\hline $80 S 2$ & 430 & 107 & 388 & 7.7 & 10.7 & 1075 \\
\hline $80 S 5$ & 214 & 54 & 376 & 7.4 & 5.4 & 1342 \\
\hline $74 S 1$ & 490 & 326 & 391 & 6.5 & 16.3 & 816 \\
\hline $74 S 2$ & 322 & 215 & 388 & 7.7 & 10.7 & 1075 \\
\hline $74 S 5$ & 161 & 107 & 376 & 7.4 & 5.4 & 1342 \\
\hline $75 S 1$ & 326 & 490 & 391 & 6.5 & 16.3 & 816 \\
\hline $75 S 2$ & 215 & 322 & 388 & 7.7 & 10.7 & 1075 \\
\hline $75 S 5$ & 107 & 161 & 376 & 7.4 & 5.4 & 1342 \\
\hline 7851 & 162 & 654 & 391 & 6.5 & 16.3 & 816 \\
\hline 7852 & 107 & 430 & 388 & 7.7 & 10.7 & 1075 \\
\hline 7855 & 54 & 214 & 376 & 7.4 & 5.4 & 1342 \\
\hline
\end{tabular}

In the first series of tests, chromium was added to uncontaminated soil from near the actual landfill site. The soil was alluvial with silty to gravelly sand type texture and a native $\mathrm{pH}$ of 8.4. Studies on trivalent chromium were performed on soil spiked with $\mathrm{CrCl}_{3} \cdot 6 \mathrm{H}_{2} \mathrm{O}$ to give $200 \mathrm{ppm} \mathrm{Cr}$ (III). Hexavalent chromium contaminated soils were produced by spiking with $\mathrm{CrO}_{3}$ to a level of $200 \mathrm{ppm} \operatorname{Cr}(\mathrm{VI})$. The dilution of the soil with grout resulted in the chromium concentrations in the treated soils being 80,106 and $135 \mathrm{ppm}$ for $\mathrm{s} / \mathrm{c}=1,2$ and 5 respectively. The second series of tests was performed on soil samples from the landfill. The samples used were retrieved from depths of $9.2,10.8$ and $12.3 \mathrm{~m}$. The reported amounts of $\mathrm{Cr}(\mathrm{VI})$ and $\mathrm{Cr}$ (total) were 291 and $6110 \mathrm{ppm}$ respectively at $9.2 \mathrm{~m}, 112$ and $138 \mathrm{ppm}$, at $10.8 \mathrm{~m}$ and 0.11 and 11.2 ppm at $12.3 \mathrm{~m} \mathrm{(9)}$. Total $\mathrm{Cr}$ of the landfill samples was measured by inductively coupled plasma spectroscopy following acid extraction in accordance with EPA SW 846 Method $3050 \mathrm{~A}$ and $\mathrm{Cr}$ (VI) was determined colorimetrically after water extraction. 


\subsubsection{Specimen Preparation}

The laboratory spiked soils were prepared by adding the required amount of predissolved $\mathrm{CrCl}_{3}, 6 \mathrm{H}_{2} \mathrm{O}$ or $\mathrm{CrO}_{3}$ to the uncontaminated soil. The amount of distilled water used to dissolve the chromium compounds was taken into account in the mix proportions. The spiked soils were either mixed by hand or with a planetary mixer, depending on the quantity. spiked soil was used immediately for preparation of grout stabilized specimens.

Grout was mixed in a blender for leach and permeability specimens or in a planetary mixer for compressive strength test cylinders. The order of addition was water, superplasticizer, bentonite, cement and any slag. For small leach and permeability specimens, the grout was mixed with the chromium contaminated soil by hand until a uniform product was achieved. Grout stabilized soil for strength cylinders was mixed in a planetary mixer.

Bentonite hydration was limited to that which occurred during mixing. Trials showed that the bentonite hydration time had little effect on grout viscosity, but did increase the gel strength. For field applications the amount of time allowed for bentonite hydration prior to mixing will depend on practicality.

It is realized that the laboratory mixing equipment differs from that which would be used in the field for treating soils. Hence, some variations in mix uniformity and final properties between laboratory prepared specimens and jet grouted or auger mixed soil can be expected.

Six cylinders $65 \mathrm{~mm}$ high and $30 \mathrm{~mm}$ diameter were cast for TCLP tests. Two of these were used and the other four were archived. Permeability and deionized water leach tests were performed on cylinders $36 \mathrm{~mm} \mathrm{high} \mathrm{and} 26 \mathrm{~mm}$ diameter. Three specimens were used for each batch. The cylinders used for strength tests were $152 \mathrm{~mm}$ high and $76 \mathrm{~mm}$ diameter and six specimens per batch were tested.

\section{2 .3 curing}

All materials were covered with plastic sheet after casting to prevent evaporation and plastic shrinkage cracking. Grout stabilized soil specimens were demoulded 24 hours after casting and cured for 28 days for leach, permeability, compressive strength, and wet-dry cycle tests. Two types of curing were used for different tests. Conventional type curing in the form of submersion in water at room temperature was conducted in order to determine the properties when adequate cement hydration occurs. simulation of the in-situ curing conditions for subsurface barriers was achieved by burying 24 hour old specimens in 2001 containers of site soil. 28 day compressive strength and wet-dry cylinders were cured in water. other test specimens, and 84 day compressive strength cylinders were cured in soil. 


\section{2 .4 Viscosity}

Viscosity of grouts was measured using a Fann 35A coaxial cylinder viscometer at $300 \mathrm{rpm}$. Measurements were taken immediately after mixing in the blender. All viscosity measurements were conducted at room temperature.

\section{2 .5 Specific Gravity}

The specific gravity of grouts and soil cements was measured using a Baroid mud balance following ASTM D 4380-84.

\section{2 .6 Flow Time}

The flow, or efflux, time of the stabilization grouts was measured using a Marsh funnel. The flow time indicates the relative flowability of grouts by measuring the time of efflux of a specific volume of grout through a standardized cone. The procedure for measuring flow time was to fill the Marsh funnel to the $1500 \mathrm{ml}$ mark and measure the efflux time for $1000 \mathrm{ml}$ of grout into a measuring cylinder. For water, the flow time of $1000 \mathrm{ml}$ initially filled to the $1500 \mathrm{ml}$ mark is 28 seconds.

\section{2 .7 Leach Tests}

Two types of leach tests were performed. These were the EPA TCLP test using Extraction Fluid \#2 $(5.7 \mathrm{ml}$ glacial acetic acid diluted to $11, \mathrm{pH}=2.88$ ) and the American Nuclear Society (ANS) 16.1 test using deionized water. The grout treated soils were cured for 28 days by burying in dry site soil prior to leach testing. In accordance with the TCLP test procedure, the cured soil cements were crushed to pass through a $9.5 \mathrm{~mm}$ sieve before testing. In addition, crushed specimens prepared from grout with $40 \% \mathrm{slag} / 60 \%$ cement and $80 \%$ slag/20\% cement were exposed to the atmosphere for seven months and re-tested to determine the effect of oxygen and carbon dioxide on the stability of the treated soil. TCLP tests were also performed on untreated spiked and landfill soils.

At the conclusion of the TCLP tests, the $\mathrm{pH}$ of the leachate was measured. The leachate was then acidified with a measured quantity of concentrated $\mathrm{HNO}_{3}$ and analyzed for hexavalent and total chromium. Atomic absorption spectrophotometry was used for total chromium measurements. Hexavalent chromium concentration was determined by reacting the acidified leachate with 1,5 diphenylcarbazide and measuring the absorbance at $540 \mathrm{~nm}$ with a UV spectrophotometer.

Preliminary TCLP tests were performed on uncontaminated soils treated with grout to determine whether detectable chromium would leach from cement or soil, thereby necessitating background correction. Analysis for iron was also conducted on the blank 
specimens to determine if sufficient iron would leach from blast furnace slag, cement or soil to interfere with measurement of total chromium by atomic absorption spectrophotometry and hexavalent chromium by colorimetry. It was found that no chromium was leached from the uncontaminated specimens and that iron concentration was less than $1 \mathrm{ppm}$, and therefore unlikely to interfere with chromium analysis. The absence of matrix effects was confirmed by analyzing uncontaminated and contaminated leachates with standard additions of chromium.

Monolithic grout treated cylinders were subjected to ANS 16.1 leach tests in deionized water for 24 weeks. Deionized water leach tests were performed on trivalent chromium soils stabilized with grouts containing 0 and $40 \%$ slag replacement and on hexavalent chromium soils stabilized with 40 and $80 \%$ slag grouts. Soil/cementitious material ratio ranged from 1 to 5 . Hexavalent chromium soils treated with ordinary Portland cement grout were not tested since previous studies show that chemical immobilization is not achieved (Kindness et al., 1994; Zamorani et al., 1988).

The leachates from the ANS 16.1 tests were analyzed and replaced daily for the first five days and subsequently every two weeks. The sampling period in the initial stages of the test was changed from the shorter intervals given in the standard because negligible release occurred in periods of 2 and 5 hours. The leachates were tested for $\mathrm{pH}$, calcium concentration and total chromium concentration. Calcium concentration was used as an indicator of leach resistance of the cementitious material since deionized water is aggressive to hydrated cement. Atomic absorption spectrophotometry was used to determine calcium concentration.

\subsubsection{Permeability coefficient}

The water permeability coefficient was measured using a rigid wall uniaxial flow permeameter. Specimens were cast in glass tubes $26 \mathrm{~mm}$ diameter and $50 \mathrm{~mm}$ long. The soil used was spiked with 200 ppm trivalent chromium. After curing in soil for 28 days the specimens were trimmed to a length of $36 \mathrm{~mm}$. The diameter of the specimens was slightly oversized to achieve a leakproof seal with the rubber gasket. The seal was further ensured by coating the gasket walls with silicone grease. Specimens were vacuum saturated with water prior to testing. The applied pressure for the permeability tests was 2 atm. Preliminary experiments conducted at different pressure gradients confirmed that flow through the grout treated soils obeyed Darcy's Law. Measurements did not commence until constant flow rate was established. Three specimens per batch were tested.

\subsubsection{Unconfined Compressive Strength}

Grout treated soil cylinders $76 \mathrm{~mm}$ diameter and $152 \mathrm{~mm}$ long were measured for unconfined compressive strength measurements following ASTM C 39-86. Measurements were conducted on six 
specimens per batch for curing times of 28 and 84 days. The 28 day cure tests were performed on soil cements cured in water and the specimens for 84 day test were cured in dry site soil. All specimens were prepared from soils spiked with 200 ppm trivalent chromium.

\subsubsection{Wet-Dry Durability Tests}

Cylinders of treated soil $76 \mathrm{~mm}$ diameter and $152 \mathrm{~mm}$ long were subjected to 12 wet-dry cycles at $25^{\circ} \mathrm{C}$. The drying temperature is lower than that of $71^{\circ} \mathrm{C}$ used in ASTM D 559-89 and was chosen as a more realistic simulation of subsurface temperatures to which the material would be exposed in the landfill. The cycles consisted of 5 hours submersion in water followed by 43 hours drying in air at relative humidity 40- 50\%. Compressive strength was measured after 24 hours soaking at the completion of the 12 wet-dry cycles. The soaking was performed to give a specimen moisture content similar to the original 28 day wet cured specimens for strength comparison purposes. Mass changes were not monitored since tests on grout treated soil conducted in FY 93 showed that variations were due to uptake and loss of moisture rather than loss of integrity.

\subsection{Results and Discussion}

\subsubsection{Unhardened Grout Properties}

The viscosities and Marsh flow times of the 74 series of grouts ( $40 \%$ slag/60\% cement) are given in Table 3. The specific gravities of the unhardened grouts are presented in Table 4.

Table 3. Rheological Properties of Unhardened Grouts

\begin{tabular}{|c|c|c|}
\hline Mix No. & Viscosity (CP) & Marsh Flow Time (s) \\
\hline $74-1$ & 46 & 52.8 \\
\hline $74-2$ & 11 & 31.2 \\
\hline $74-5$ & 4 & 28.2 \\
\hline
\end{tabular}

The 74 series of grouts had relatively low viscosities and low flow times. The mix proportions of these grouts could be altered to suit the flow requirements of the chosen placement technique if necessary. The specific gravity data showed the expected decrease in values as the amount of slag replacement for cement increased, due to the lower specific gravity of slag itself. 
Table 4. Specific Gravities of Unhardened Grouts

\begin{tabular}{|c|c|}
\hline Mix No. & Specific Gravity \\
\hline $47-1$ & 1.85 \\
\hline $47-2$ & 1.66 \\
\hline $47-5$ & 1.40 \\
\hline $58-5$ & 1.38 \\
\hline $80-1$ & 1.84 \\
\hline $80-2$ & 1.65 \\
\hline $80-5$ & 1.39 \\
\hline $74-1$ & 1.82 \\
\hline $74-2$ & 1.63 \\
\hline $74-5$ & 1.38 \\
\hline $75-1$ & 1.81 \\
\hline $75-2$ & 1.62 \\
\hline $75-5$ & 1.38 \\
\hline $78-1$ & 1.79 \\
\hline $78-2$ & 1.61 \\
\hline $78-5$ & 1.37 \\
\hline
\end{tabular}

\section{$\underline{2.3 .2}$ TCLP Tests}

The results of the TCLP tests on $200 \mathrm{ppm} \mathrm{Cr(III)} \mathrm{spiked} \mathrm{soil}$ treated with plain and slag modified grout are shown in Figure 1. The effect of slag content and soil/cementitious material ratio are evident. The grout without any slag has the greatest amount of leached $\mathrm{Cr}$, but the level remains below the EPA limit of $5 \mathrm{ppm}$. At the $80 \%$ slag replacement level no chromium was detected in the leachate. Hence, it is apparent that addition of slag improves the TCLP leach resistance of grout stabilized trivalent chromium and that high amounts of soil can be added to the grout without detriment to TCLP leachability. The concentration of chromium leached from spiked unstabilized soil was $6.3 \mathrm{ppm}$.

The silica fume modified mix was used to stabilize $200 \mathrm{ppm}$ $C r$ (III) spiked soil at a $s / c=5$ (5855). The total leached $\mathrm{Cr}$ was $0.3 \mathrm{ppm}$ and the leachate $\mathrm{pH}$ was 11.03. The amount of leached chromium was the same as that for the plain grout (4755), and higher than the slag modified mixes.

The leachate $\mathrm{pH}$ values of the grouted soils with 200 ppm 


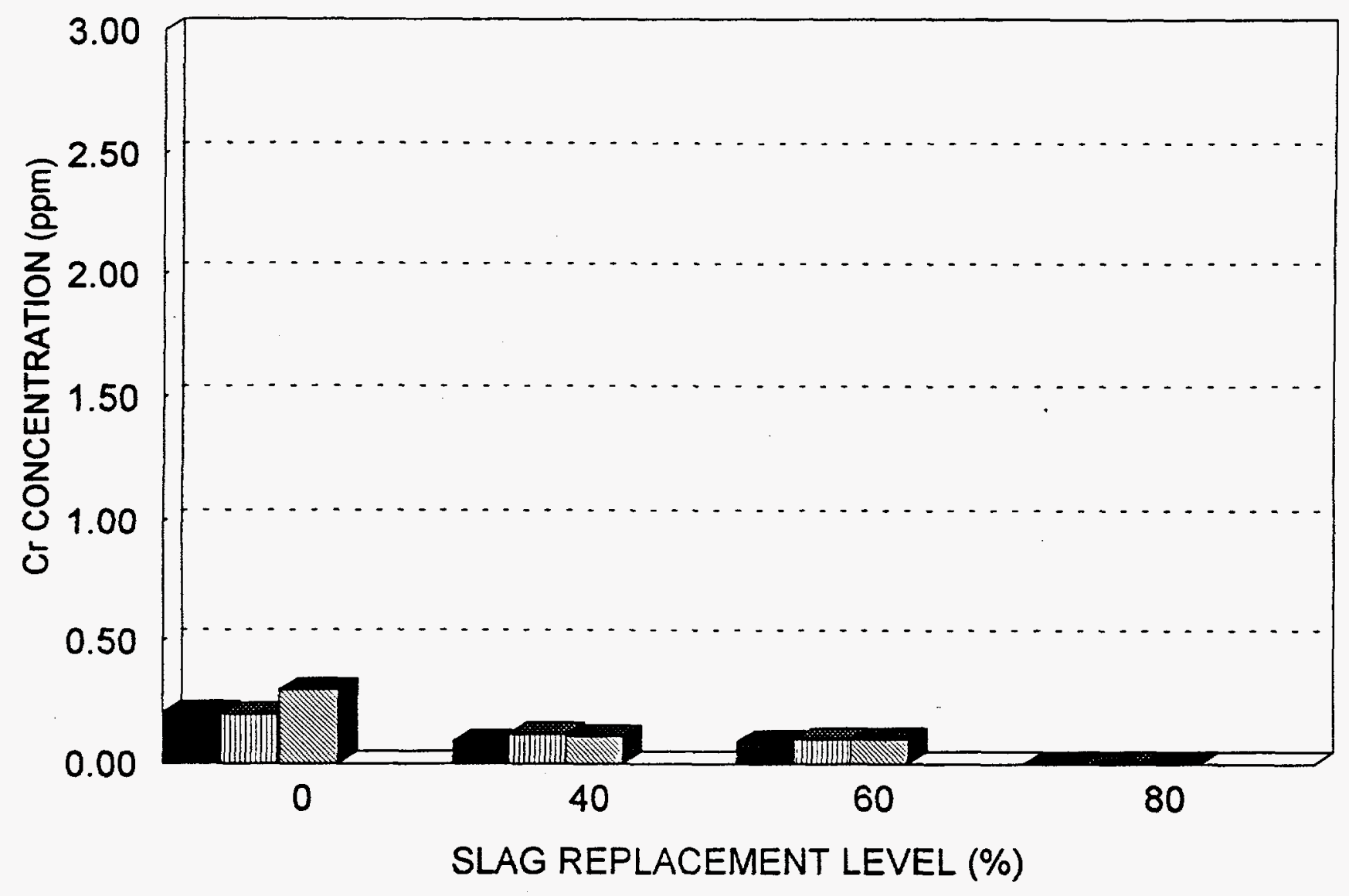

Figure 1. TCLP results for $200 \mathrm{ppm}$ Cr(III) soil treated with slag modified grouts. 
Cr(III) are shown in Figure 2. The corresponding leachate pH of the unstabilized soil was 5.82. As indicated, the pH decreases with increasing soil/cementitious material ratio and with increasing slag content. The higher $\mathrm{pH}$ of the Portland cement grout may result in increased solubility of chromium.

The concentrations of hexavalent and total chromium in the leachate from $\mathrm{Cr}$ (VI) spiked specimens are plotted against amount of slag for $s / c=1$ to 5 in Figures 3 to 5 . In all cases, the greatest amount of chromium is leached from the specimens without slag, and leachate concentrations decrease with increasing slag replacement of cement. The leached chromium remains below EPA limits for all mixes. However, the ordinary Portland cement grout is not expected to give permanent chemical stabilization of Cr(VI) (Kindness et al., 1994; Zamorani et al., 1988). The leach resistance of the soil treated with ordinary portland cement is probably due to physical containment, rather than chemical stabilization.

A significant feature of Figures 3 to 5 is that the proportion of chromium that is in the hexavalent state is reduced with increasing slag replacement level. This indicates reduction to $\mathrm{Cr}$ (III). When slag is absent the majority of leached chromium is in the undesirable hexavalent state. The results show that slag replacement levels equal or greater than $40 \%$ give the best leach resistance, even at high soil loadings. The untreated soil spiked with $200 \mathrm{ppm} \mathrm{Cr}$ (VI) had leachate concentrations of $8.75 \mathrm{ppm}$ Cr(VI) and $9.5 \mathrm{ppm} \mathrm{Cr}$ total. It is possible that ferrous ions within the soil caused some conversion of $\mathrm{Cr}$ (VI) to $\mathrm{Cr}$ (III).

The $\mathrm{pH}$ values of the leachates from the treated $200 \mathrm{ppm} \mathrm{Cr}$ (VI) soils are shown in Figures 6 . The values are similar to those for the $200 \mathrm{ppm}$ Cr(III) soils treated with grout with the same mix proportions. The untreated soil had a leachate $\mathrm{pH}$ of 5.49. Some neutralization of the soil by the added $\mathrm{CrO}_{3}$ probably occurred.

Another possible $\mathrm{Cr}$ (III) stabilization mechanism is substitution for $\mathrm{Al}^{3+}$ ions in bentonite used in the grouts. It is also possible that $\mathrm{Cr}^{3+}$ is adsorbed on bentonite (Connor, 1990). However, these mechanisms would only account for a small proportion of the total stabilization since a low amount of bentonite was used.

Specimens with $\mathrm{s} / \mathrm{c}=5$ prepared from grout with $80 \%$ slag replacement exhibited surface cracks after the 28 day curing period in dry soil. The cracks are attributed to excessive drying shrinkage and this deterioration is of concern.

Leach tests were performed on $200 \mathrm{ppm} \operatorname{Cr}$ (VI) spiked soil stabilized with grout containing $40 \%$ slag/60\% cement that was crushed after curing and exposed to air for seven months. The results are shown in Figure 7 . The initial results for the same mixes are also shown. Comparison indicates that the concentrations of hexavalent and total chromium are similar for the two series of tests when $s / c=1$ and 2 . This indicates stability when the grout 


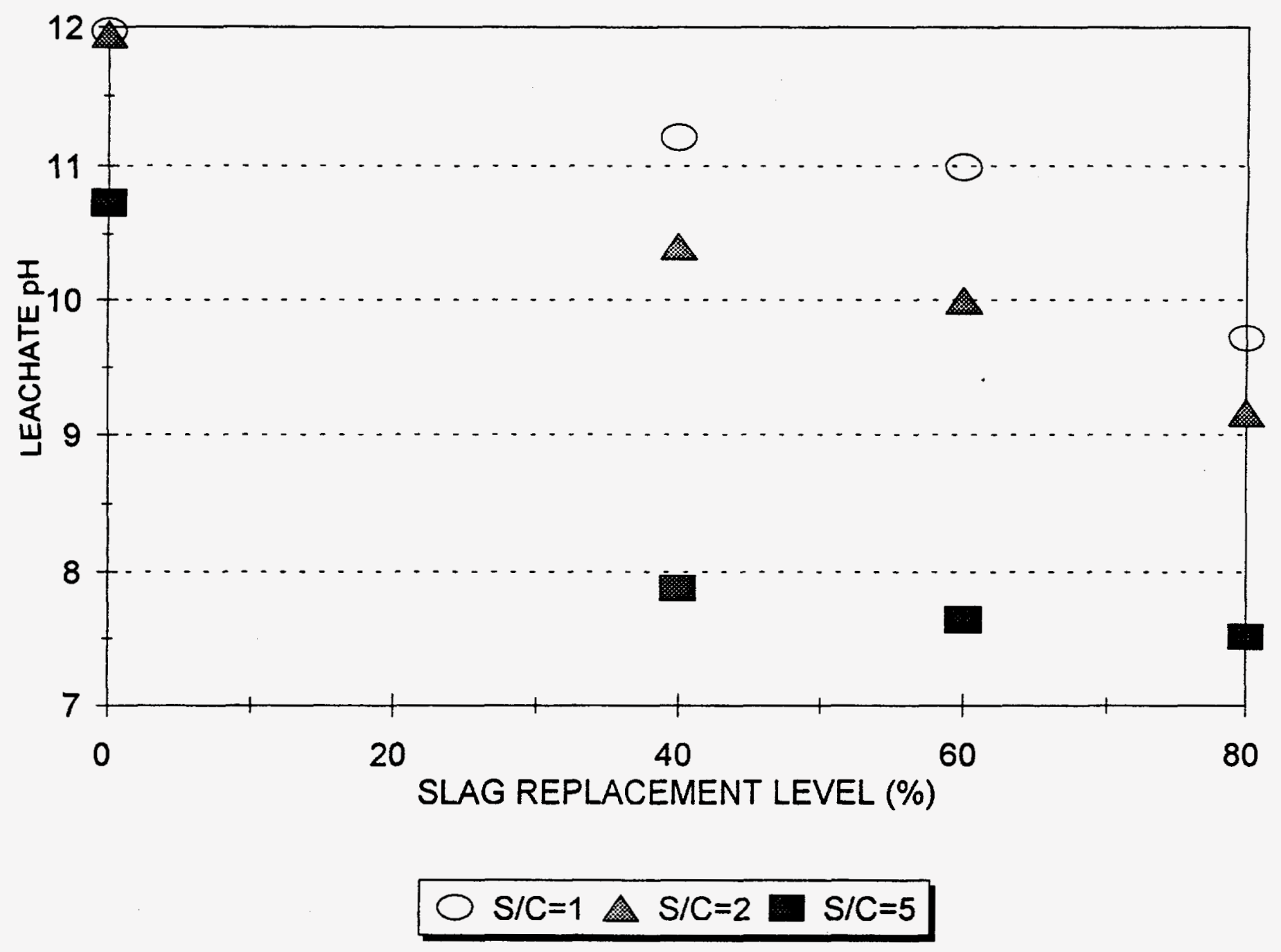

Figure 2. TCLP leachate $\mathrm{pH}$ for $200 \mathrm{ppm}$ Cr(III) soil treated with slag modified grouts. 


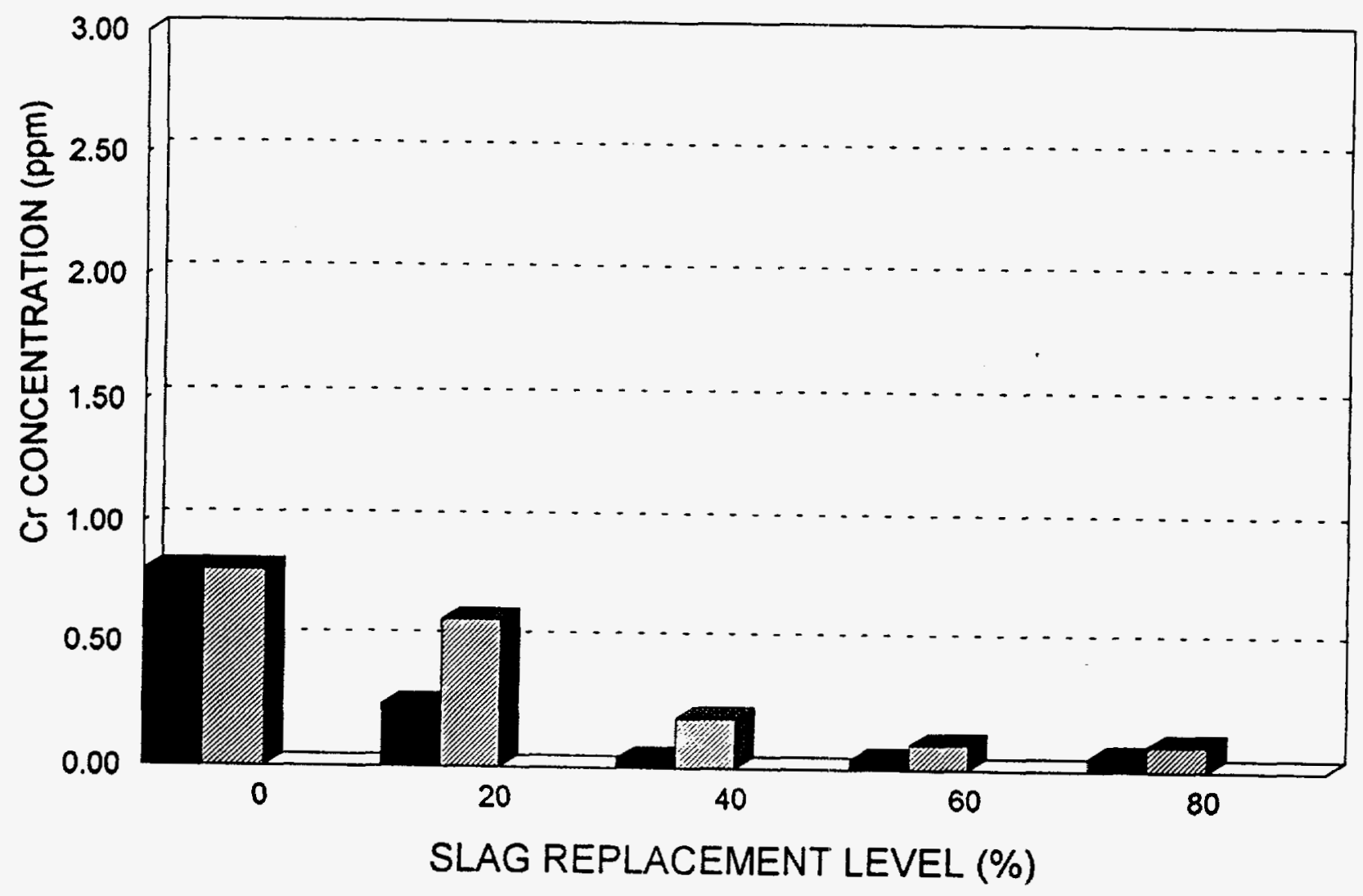

$\square \mathrm{Cr}(\mathrm{VI}) \quad \mathrm{Cr}(\mathrm{TOTAL})$

Figure 4. TCLP results for $200 \mathrm{ppm}$ Cr(VI) soil treated with slag modified grouts at soil/cementitious material ratio $=2$. 


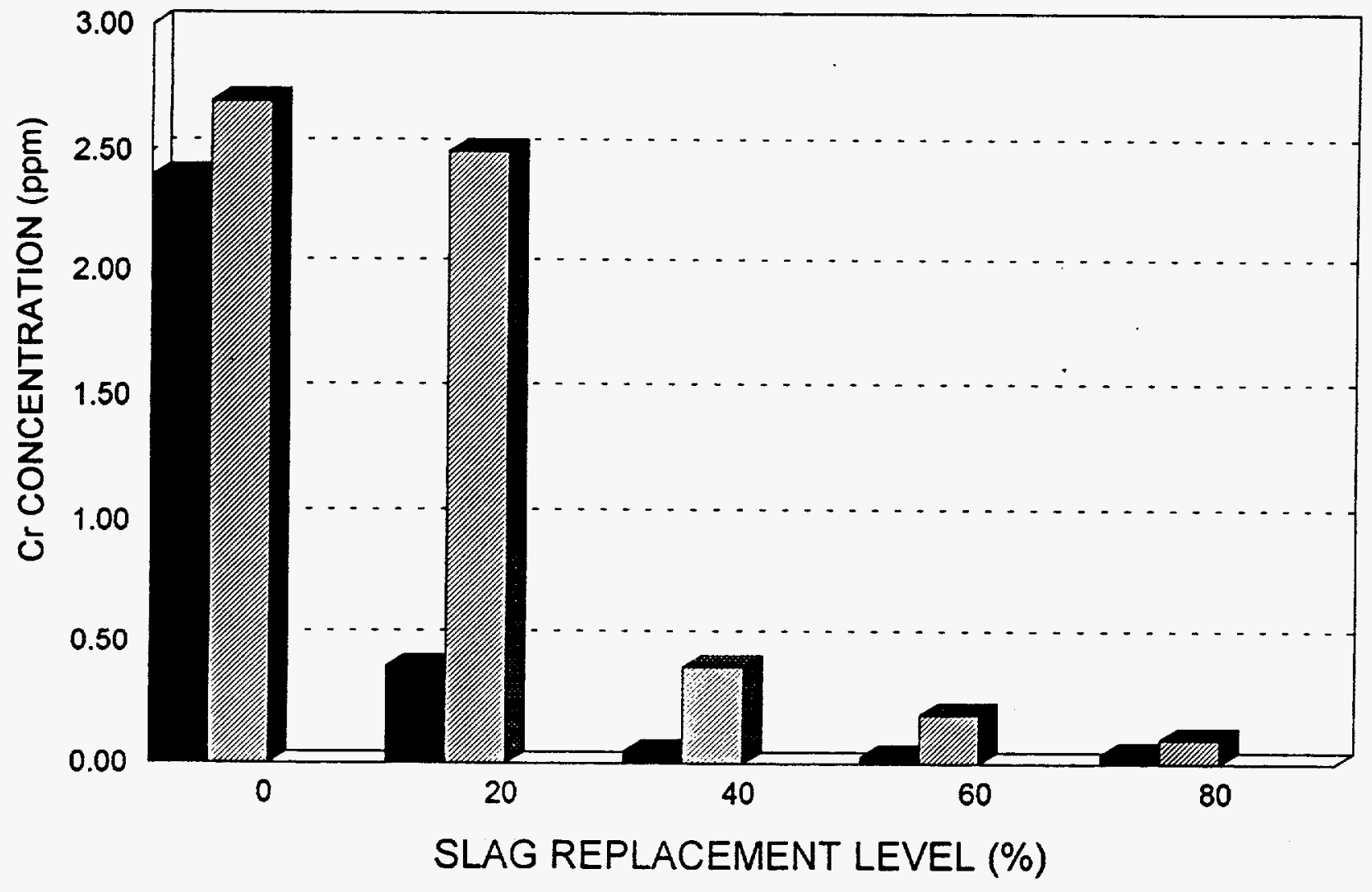

Cr $\mathrm{Cr}(\mathrm{VI}) \quad \mathrm{TOTAL})$

Figure 5. TCLP results for $200 \mathrm{ppm}$ Cr(VI) soil treated with slag modified grouts at soil/cementitious material ratio $=5$. 


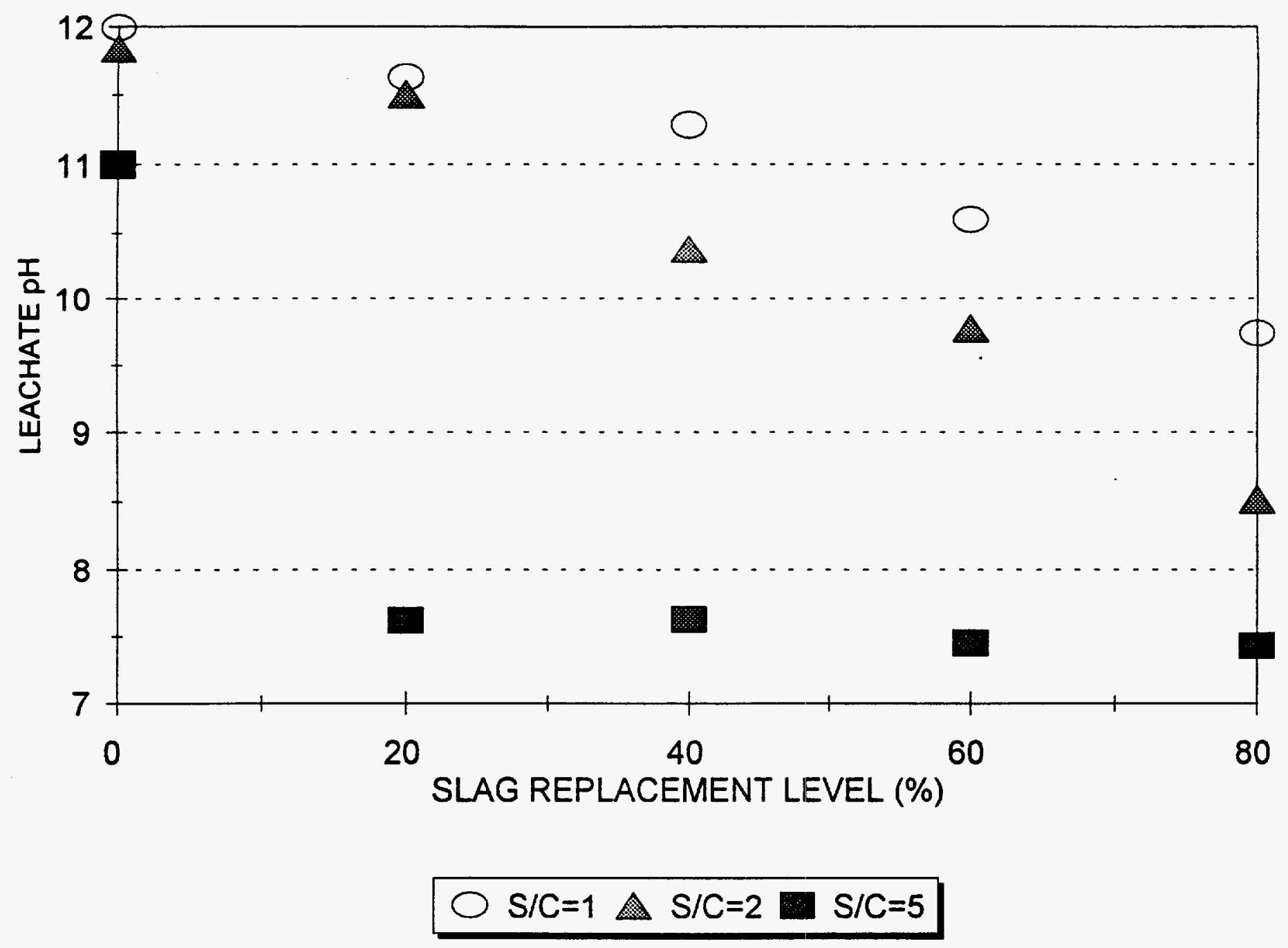

Figure 6. TCLP leachate $\mathrm{pH}$ for $200 \mathrm{ppm} \operatorname{Cr}(\mathrm{VI})$ soil treated with slag modified grouts. 


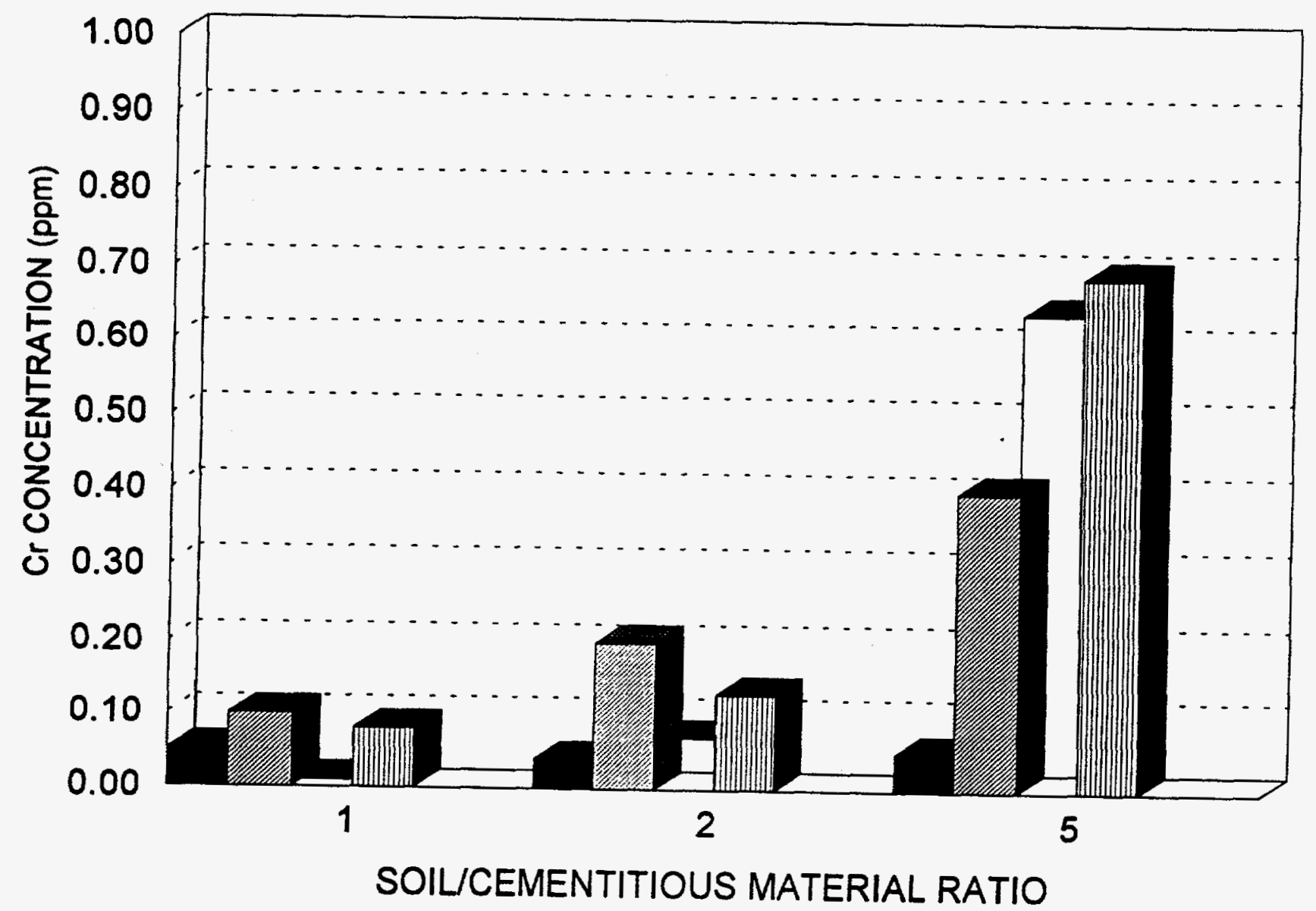

$\square \mathrm{Cr}(\mathrm{VI})$ Initial $\mathrm{Cr}($ Total) Initial $\square \mathrm{Cr}(\mathrm{VI})$ Final $\mathrm{Cr}$ (Total) Final

Figure 7. TCLP results for $200 \mathrm{ppm}$ Cr(VI) soil treated with 408 slag/60\% cement grout before and after exposure to air for 7 months. 
treated soil is exposed to oxygen and carbon dioxide. However, when $s / c=5$, the amount of leached chromium is significantly higher after seven months exposure. It is also significant that most of the leached chromium from the exposed $\mathrm{mix}$ with $\mathrm{s} / \mathrm{c}=5$ is in the hexavalent state. The results for crushed and leached specimens prepared from $80 \%$ slag/20\% cement grout are depicted in Figure 8 , along with the initial 28 day results. It is evident that the leachate chromium concentrations are similar before and after exposure to air. At $s / c=5$, the total $C r$ after air exposure was $0.15 \mathrm{ppm}$ compared with $0.10 \mathrm{ppm}$ at 28 days and $\mathrm{Cr}$ (VI) levels were similar $(0.04 \mathrm{ppm}$ at 28 days and $0.03 \mathrm{ppm}$ after seven months exposure). Thus, the large increase in $\mathrm{Cr}$ (VI) concentration observed with the $40 \% \mathrm{slag} / 60 \%$ cement grout was not repeated for that with $80 \%$ slag/20\% cement. It is possible that the higher Cr(VI) level with $40 \%$ slag was due to an anomaly such as nonuniform mixing.

The $\mathrm{pH}$ of the leachates from the seven month old crushed specimens was lower than the original values. For $40 \%$ slag/60\% cement grout the $\mathrm{pH}$ values were $6.87,6.90$ and 6.73 for $\mathrm{s} / \mathrm{c}=1,2$ and 5 respectively, compared with original values of $11.28,10.38$ and 7.63. For $80 \% \mathrm{slag} / 20 \%$ cement grout the leachate $\mathrm{pH}$ values were $6.91,7.27$ and 6.35 for $\mathrm{s} / \mathrm{c}=1,2$ and 5 . respectively, compared with initial values of $9.74,8.52$ and 7.43 . The reduction in leachate $\mathrm{pH}$ is due to carbonation of the cementitious material caused by reaction with atmospheric carbon dioxide.

Slag replacement levels of $40 \%$ and $s / C$ values of 1 and 2 were selected for TCLP studies on contaminated soil from the landfill. The results for the treated and untreated soils are given in Table 5 .

Table 5. TCLP Results for Landfill soils Treated with $40 \%$ slag/ 60\% Cement Mix (74)

\begin{tabular}{||c|c|c|c|c||}
\hline $\begin{array}{c}\text { Soil } \\
\text { Sample }\end{array}$ & s/C & $\begin{array}{c}\text { Leachate } \\
\mathrm{pH}\end{array}$ & $\begin{array}{c}\text { Leachate Cr } \\
\text { (VI) (ppm) }\end{array}$ & $\begin{array}{c}\text { Leachate Cr } \\
\text { Total (ppm) }\end{array}$ \\
\hline $9.2 \mathrm{~m}$ & 1 & 11.07 & 0.04 & 0.37 \\
\hline $9.2 \mathrm{~m}$ & 2 & 10.46 & 0.55 & 0.83 \\
\hline $9.2 \mathrm{~m}$ & Untreated & 5.28 & 11.5 & 14.3 \\
\hline $10.8 \mathrm{~m}$ & 1 & 11.28 & 0.01 & 0.17 \\
\hline $10.8 \mathrm{~m}$ & 2 & 10.62 & 0.03 & 0.14 \\
\hline $10.8 \mathrm{~m}$ & Untreated & 4.34 & 1.00 & 1.10 \\
\hline $12.3 \mathrm{~m}$ & 1 & 11.18 & 0.00 & 0.08 \\
\hline $12.3 \mathrm{~m}$ & 2 & 9.97 & 0.00 & 0.08 \\
\hline $12.3 \mathrm{~m}$ & Untreated & 5.74 & 0.05 & 0.09 \\
\hline
\end{tabular}




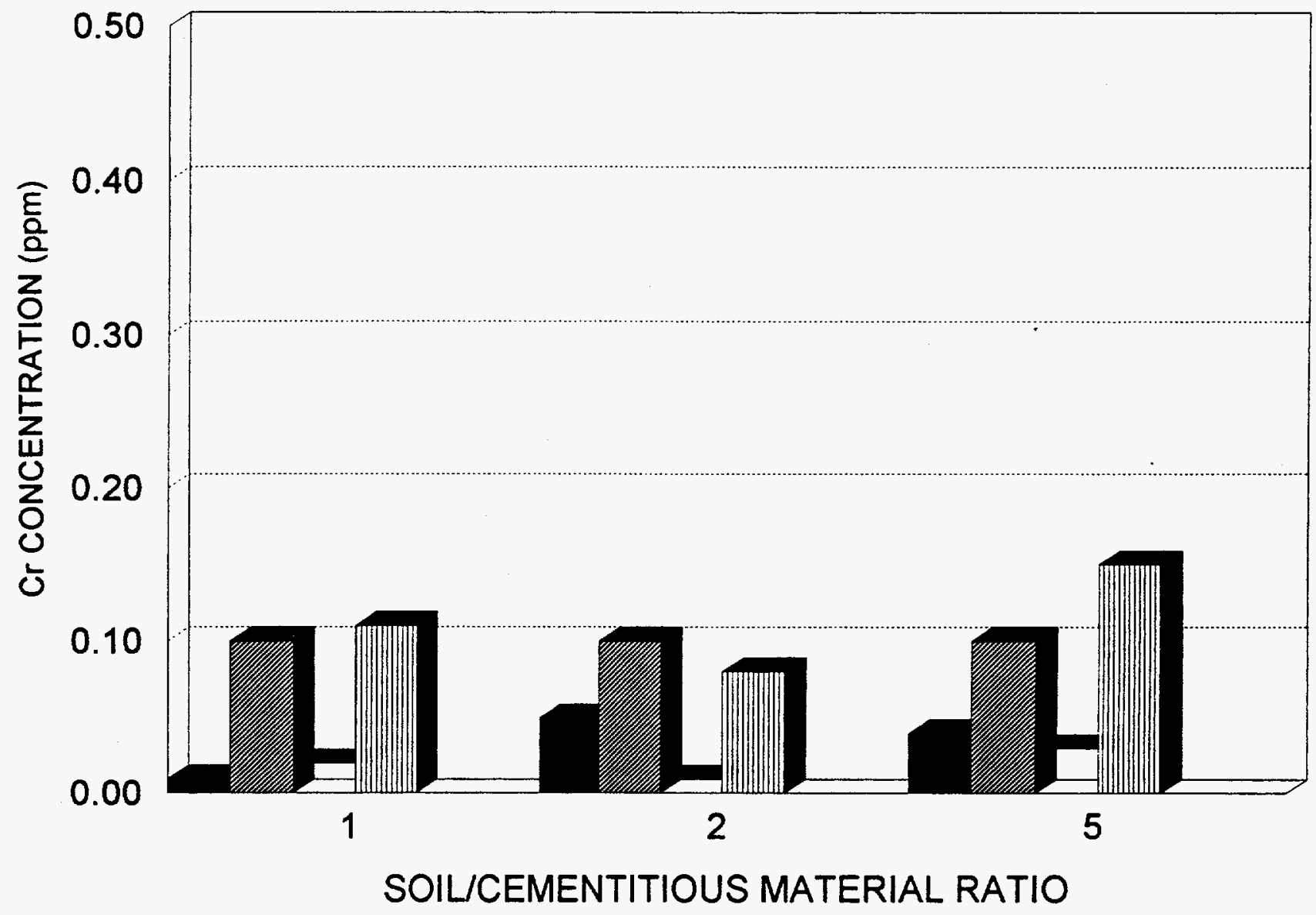


The majority of TCLP leachable chromium from the untreated landfill soils was in the hexavalent state. The unleached $10.8 \mathrm{~m}$ sample was the closest in original chromium analysis to that of the spiked soils with $112 \mathrm{ppm} C r(V I)$ and $138 \mathrm{ppm}$ total $\mathrm{Cr}$. The spiked soils had significantly higher leached concentrations than this landfill soil ( $8.75 \mathrm{ppm} C r(V I)$ for spiked soil compared with 1.00 ppm $\operatorname{Cr}(V I)$ for landfill soil). This suggests that the landfill soil was less leachable than the spiked soil which could be due to formation of low solubility chromium complexes with soil compounds and diffusion of chromium into rocks over time.

The slag modified grout successfully immobilized $\operatorname{Cr}$ (VI) in the landfill soil. It is planned to repeat the TCLP tests on crushed samples exposed to air to determine the longevity of stabilization by these grouts.

Factors affecting the TCLP results include crushed particle size. As the $s / C$ value and slag replacement level increased, the treated soils were weaker and tended to fragment into smaller pieces when crushed. Since the TCLP sample preparation procedure requires that material passes through a $9.5 \mathrm{~mm}$ sieve and does not give any lower bounds on particle size, finer pieces are accepted. The result is that the weaker specimens tended to have greater surface area exposed to leachate. This is expected to increase the leachate $\mathrm{pH}$ and increase the leachate chromium concentration compared with the same material tested with a greater particle size.

\subsubsection{Deionized Water Leach Tests}

The mean final leachate $\mathrm{pH}$ and cumulative leached calcium and chromium for the stabilized spiked soils are presented in Table 6. The oxidation state of the chromium added to the soil is indicated after the mix number.

The leachate $\mathrm{pH}$ remained alkaline for all the tested materials. No detectable chromium was leached from the specimens prepared with $200 \mathrm{ppm}$ Cr(III) spiked soil. Chromium leached in the early stages of the tests from the $\operatorname{Cr}$ (VI) spiked soils stabilized with $40 \% \mathrm{slag} / 60 \%$ cement grout at $\mathrm{s} / \mathrm{C}=5$ and with the $80 \% \mathrm{slag} / 20 \%$ cement grout at $\mathrm{s} / \mathrm{c}=2$ and 5 . The cumulative leached fractions for chromium were $0.025,5.9 \times 10^{-3}$ and $5.1 \times 10^{-3}$ for mixes 74 S5 (VI), $78 \mathrm{~S} 2$ (VI) and 7855 (VI) respectively. Leaching of chromium ceased after 4 weeks.

The deionized water leach test is probably more representative of the exposure conditions for the landfill under study than the TCLP test since exposure to organic acid leachants is not expected. Hence, the low leachability of chromium observed in the deionized water tests is indicative of acceptable immobilization for existing field conditions. 
Table 6. Results for Deionized Hater Ieach Tests

\begin{tabular}{|c|c|c|c|}
\hline Mix & Final Leachate & $\begin{array}{c}\text { Mean } \\
\text { Cumulative } \\
\text { Leached Ca } \\
\text { (mg) }\end{array}$ & $\begin{array}{c}\text { Maximum } \\
\text { Cumulative } \\
\text { Leached Cr } \\
\text { (mg) }\end{array}$ \\
\hline 4755 (III) & $10.49 \pm 0.01$ & $352 \pm 2$ & 0.00 \\
\hline 7451 (III) & $10.49 \pm 0.05$ & $345 \pm 4$ & 0.00 \\
\hline 7452 (III) & $10.30 \pm 0.30$ & $169 \pm 2$ & 0.00 \\
\hline 7455 (III) & $10.41 \pm 0.05$ & $282 \pm 2$ & 0.00 \\
\hline 7451 (VI) & $10.60 \pm 0.11$ & $373 \pm 2$ & 0.00 \\
\hline 7452 (VI) & $10.29 \pm 0.13$ & $281 \pm 2$ & 0.00 \\
\hline 7455 (VI) & $10.40 \pm 0.02$ & $313 \pm 3$ & 0.13 \\
\hline 7851 (VI) & $10.28 \pm 0.03$ & $215 \pm 3$ & 0.00 \\
\hline 7852 (VI) & $10.22 \pm 0.02$ & $222 \pm 2$ & 0.024 \\
\hline 7855 (VI) & $10.13 \pm 0.06$ & $205 \pm 2$ & 0.026 \\
\hline
\end{tabular}

The total amount of calcium leached from the stabilized soils decreased as slag content increased, reflecting the lower original inventory of calcium. The cumulative leached fraction could not be calculated accurately because the original calcium concentrations of the specimens were unknown. However, estimations of cumulative leached fractions for comparative purposes were made using the calcium content of the cement and slag used in the mixes and assuming a value of soil calcium content. The estimations from the results for the $\mathrm{Cr}$ (VI) spiked soils showed that the approximate cumulative leached fraction of calcium was higher for the $40 \%$ slag/60\% cement than the $80 \%$ slag/20\% cement mixes for the same soil calcium content. Cumulative leached fraction of calcium was also estimated to increase with increasing soil content, the degree depending on the assumed value of calcium in the soil. The increased leached fraction of calcium as soil content increased is due to the corresponding higher water/cementitious material ratios and associated greater leachability of cement rather than the soil content itself since estimations assuming calcium free soil show the same trend.

\subsubsection{Permeability Coefficient}

The permeability coefficients of the grout treated $\mathrm{Cr}$ (III) soils after 28 days curing in dry soil are shown in Figure 9. The error bars represent one standard deviation. Permeability gives a measure of durability and resistance to penetration by most aggressive species will improve as permeability decreases. The results show the expected trend of permeability increasing as soil 


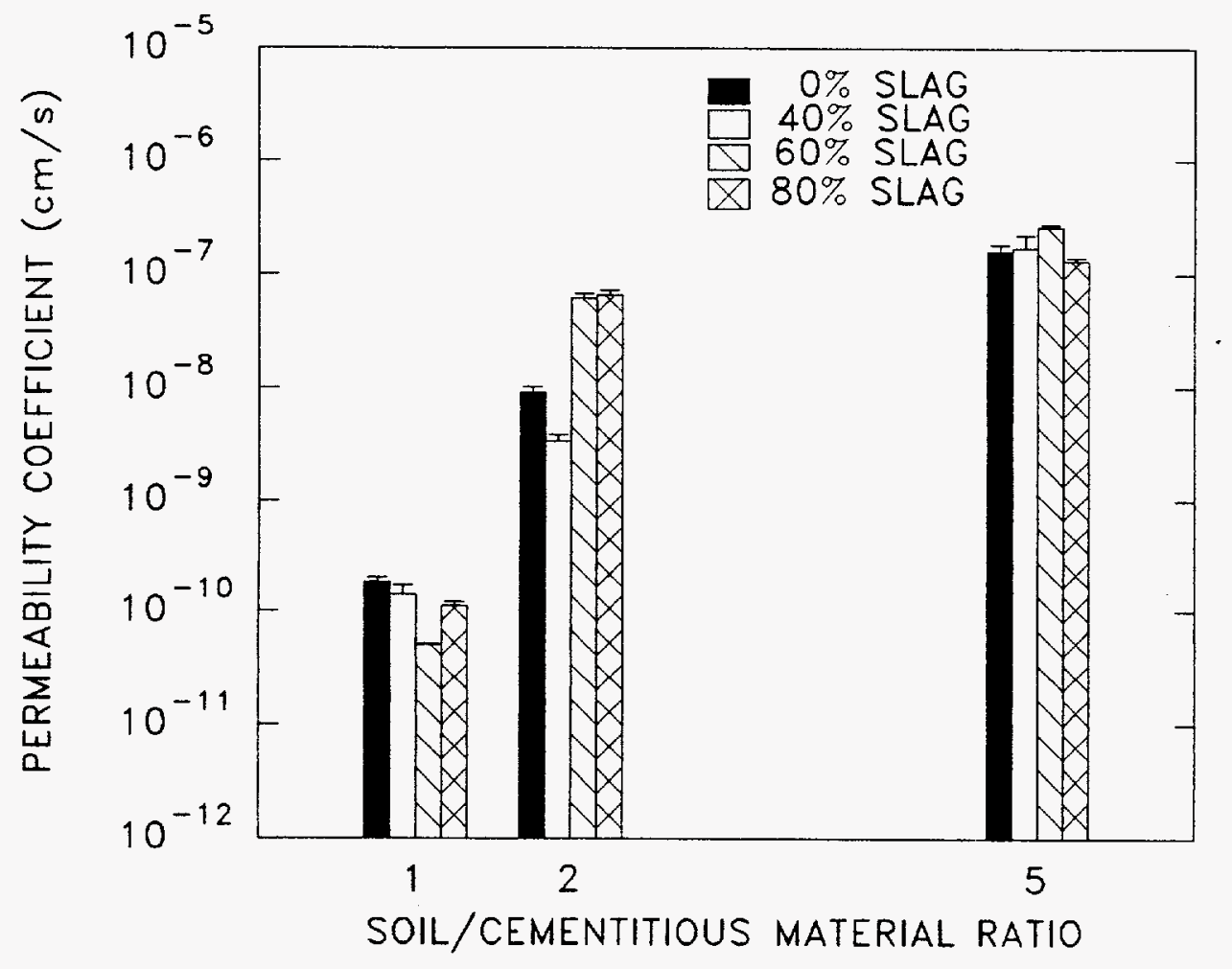

Figure 9. Permeability coefficient versus soil/cementitious material ratio for $200 \mathrm{ppm} C r$ (III) soil treated with slag modified grouts. 
and water content increases. At high soil contents the permeability is probably controlled by flow through uncemented soil particles. Any connected microcracks will also increase permeability. Surface microcracking was not observed on the $80 \%$ slag $\mathrm{mix}$ with $\mathrm{s} / \mathrm{C}=5$, although cracks were present on the larger TCLP specimens. The effect of slag replacement level on permeability of the treated soil is variable, and is not significant at $s / c=5$.

The permeabilities were reasonably low, thereby indicating resistance to liquid penetration. Further work is necessary to determine whether the same low values can be achieved under field conditions.

\subsubsection{Compressive Strength}

The mean 28 day wet cured compressive strengths and standard deviations for the $200 \mathrm{ppm} C r$ (III) soils stabilized with grout are given in Table 7. Figure 10 shows the effect of slag replacement level and soil/cementitious material ratio on compressive strength graphically. The error bars represent one standard deviation. Strength decreases with increasing slag content when $s / C=1$ and 2 . At $\mathbf{s} / \mathbf{c}=5$, strength tends to increase as slag content increases. The strengths of the stabilized soils are adequate for withstanding overburden loads and occasional vehicular traffic.

Compressive strengths were also measured on specimens prepared from the 408 slag replacement grout (74) after 84 days curing in dry soil. The results are given in Table 8 . Slight increases in strength occurred with time for the buried specimens, although dry soil curing conditions were not ideal for cementitious materials. 


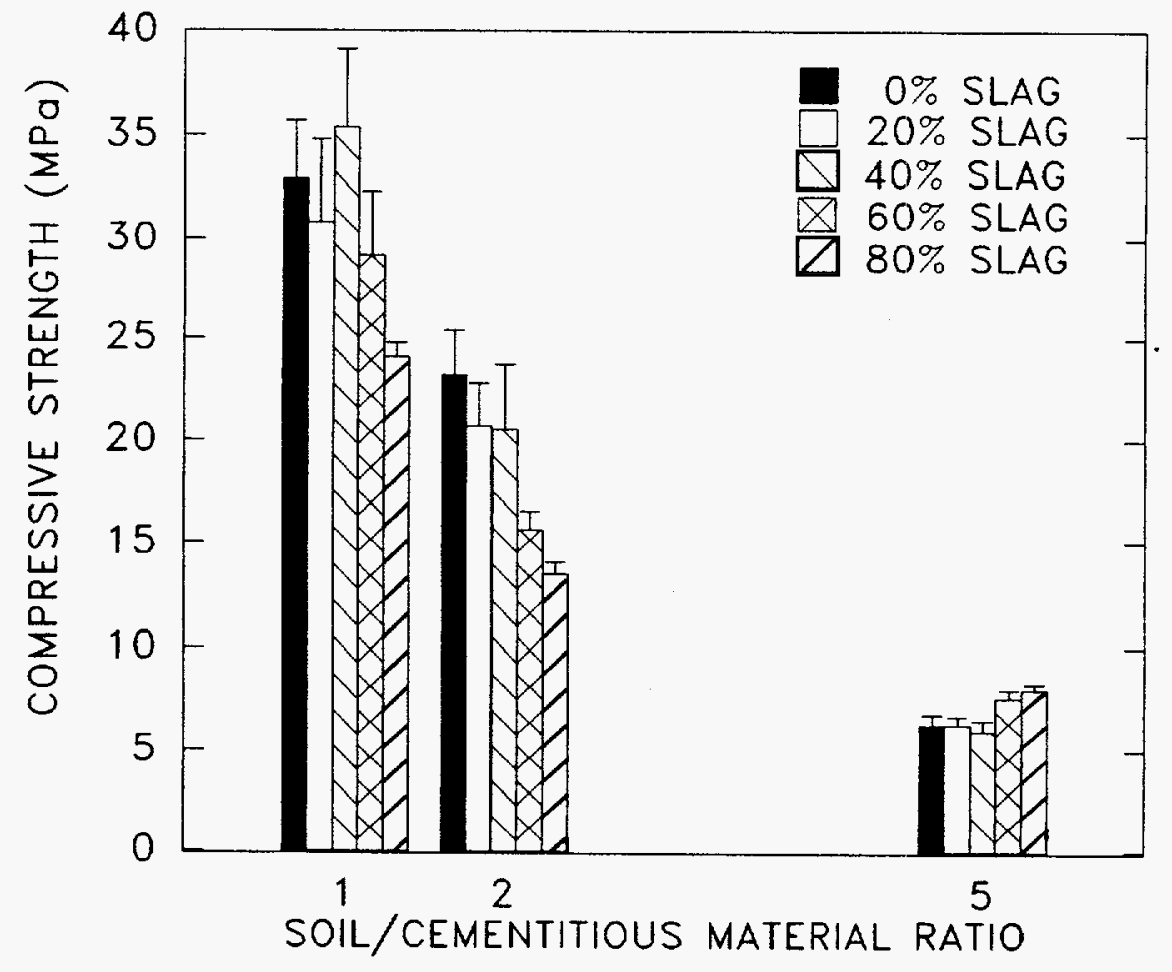

Figure 10. Compressive strength versus soil/cementitious material ratio for $200 \mathrm{ppm}$ Cr(III) soil treated with slag modified grouts. 
Table 7. 28 Day wet cured Compressive strength of stabilized soil

\begin{tabular}{|c|c|}
\hline Mix No. & 28 DaY Compressive Strength \\
(MPa)
\end{tabular}

Table 8. 84 Day soil cured Compressive strength of stabilized soil

\begin{tabular}{|c|c|}
\hline Mix No. & 84 Day Compressive strength \\
(MPa)
\end{tabular}

\subsection{6 wet-Dry Cycling}

The grouted treated soils developed surface cracks after the second wet-dry cycle. Cracking is due to stresses induced by cycles of drying shrinkage and followed by swelling of the surface layer. Crack widths were greatest on the specimens with $\mathbf{s} / \mathbf{c}=5$, 
particularly those with $80 \%$ slag replacement for cement (7855). All of the specimens remained intact. Table 9 presents the residual compressive strengths of the stabilized soils after 12 wet-dry cycles.

Table 9. Residual Compressive strength of stabilized soil

\begin{tabular}{|c|c||}
\hline Mix No. & $\begin{array}{c}\text { Residual Compressive Strength } \\
\text { (MPa) }\end{array}$ \\
\hline 4751 & $37.8 \pm 5.5$ \\
\hline 4752 & $33.1 \pm 0.3$ \\
\hline 4755 & $10.1 \pm 0.5$ \\
\hline $74 S 1$ & $33.3 \pm 3.0$ \\
\hline 7452 & $22.3 \pm 3.9$ \\
\hline 7455 & $7.2 \pm 0.5$ \\
\hline $75 S 1$ & $34.7 \pm 1.3$ \\
\hline $75 S 2$ & $17.9 \pm 2.5$ \\
\hline $75 S 5$ & $8.3 \pm 0.1$ \\
\hline 7851 & $25.2 \pm 0.7$ \\
\hline 7852 & $12.9 \pm 1.6$ \\
\hline 7855 & $6.4 \pm 0.5$ \\
\hline
\end{tabular}

Comparison between Tables 7 and 9 shows that the residual strengths are similar or slightly higher than the 28 day wet cured strengths, despite cracking of the cylinders after repeated wetting and drying. It is possible that the apparent strength increases are associated with moisture differences between the wet cured and the wet-dry cycle specimens. The wet-dry specimens were soaked for 24 hours prior to testing to reduce moisture variations, but this time period may have been insufficient to give a moisture content similar to that of the wet cured specimens. Wet-dry cycle induced cracking is also expected to have less effect on compressive strength than on flexural strength, depending on crack orientation with respect to applied load.

The wet-dry cycle tests are an aggressive acceleration of site exposure conditions. Low rainfall, combined with subsurface protection, will reduce the risk of deterioration. If cracking of the stabilized soil does occur, the greatest consequence is increased risk of penetration by water or other fluids. Subsurface barriers and caps should minimize external penetration to the stabilized soil. 


\subsubsection{General Discussion of In-Situ Stabilization}

stabilization of hexavalent and trivalent chromium contaminated soils with slag modified grouts appears a viable onestage remedial option. The results indicate that leach resistance, impermeability and mechanical strength of treated soil can be achieved. While high soil loadings can be used, superior durability and stability are expected with soil/cementitious material ratios less than 5. Water/cementitious material ratio of the grout is also a significant factor in controlling the performance of the stabilized soil and lower values are favoured. A grout with $40 \%$ slag/60\% cement and $s / c=1-2$ gives the best combination of properties. Higher slag contents have lower leached $\mathrm{Cr}$ in TCLP tests and lower leached Ca in deionized water tests, but observations of shrinkage cracking in some specimens suggests that high slag contents may be undesirable. Field testing with appropriate mixing and placement equipment is necessary to further optimize grout mix proportions and waste loadings.

The ability of the soil stabilized with slag modified mixes to pass TCLP tests even at high soil and water contents also signifies that the grout treatment process has a forgiving nature. Temporary aberrations in process control, within limits, may not necessarily obstruct successful stabilization.

Use of slag in treatment grouts may also contribute benefits such as resistance to sulphate attack. For treatment of the chromium plume the temperature and heat generated by grout must be considered since this may result in thermal cracking. In the proposed remediation, grout would be mixed in-situ with contaminated soil to give an array of interconnected columns, each approximately 1 to $2 \mathrm{~m}$ diameter and up to $25 \mathrm{~m}$ deep, depending on plume depth at a given location. If heat dissipation is inhibited by surrounding soil, excessive thermal stresses may eventuate, particularly if conditions approach adiabatic. Addition of slag and optimization of soil/grout ratio to reduce heat generation, but retain adequate toughness, will reduce the risk of thermal cracking.

\subsubsection{Recommendations for Future Work on In-Situ Stabilization}

Several aspects of in-situ stabilization of chromium contaminated soil with slag modified grouts require investigation before full-scale remediation can be implemented. The data give a foundation that justifies further fine tuning so that the process can be applied with the greatest degree of success.

The aspect of greatest importance in transferring the slag modified grout treatment to full-scale use is field trials to determine the optimum grout flow properties (and hence, water/cementitious material ratio) and equipment parameters for the 
chosen placement method. This would best be achieved through conducting field trials on grouts with different mix proportions and varying the placement equipment parameters in a systematic manner. An uncontaminated site with soil conditions similar to those of the actual landfill is required for these field trials. The dimensions and quality of the stabilized soil would then be determined and correlated with the materials and equipment parameters used. Mixes $74-1$ and $74-2$ are recommended for field trials. Variations of these should also be tested, with the objective of minimizing the water/cementitious material ratio that is compatible with the placement technique and final product quality.

The field trials must be conducted in conjunction with an experienced, professional grouting contractor with appropriate mixing and placement equipment. Successful remediation and optimum value from field trials will require full cooperation from a suitably qualified contractor, since success not only depends on the grout material but also the care and competency with which it is placed. It is also recommended that a contractor from private industry be used so that technology transfer is enhanced. Jet grouting and deep soil mixing are the recommended placement techniques. It is emphasized here, and in a future section of this report, that permeation grouting with the grouts used in this work is inappropriate for the site conditions and totally unsuitable for stabilization of the chromium plume.

simplification of the grout batching process should also be investigated. Type Is cement is a blend of ground granulated blast furnace slag and Portland cement in which the slag comprises 25 to 75\% of the total mass. These amounts are within the range of the mixes studied. While $20 \%$ slag replacement did not convert all of the hexavalent chromium, a value of $25 \%$ may give better results. If Type IS cement is successful in stabilizing $\mathrm{Cr}$ (VI) contaminated soil it would not be necessary to add cement and slag in separate stages, and this would simplify grout production. A concern with Type Is cement is that the variable slag content may give variable stabilization capacity. By performing TCLP tests on soils stabilized by Type Is cement with different slag contents, the suitability of this cement can be evaluated.

Further durability tests of the stabilized soil should be conducted. In particular, resistance to deterioration caused by soluble sulphates and sulphur oxidizing bacteria that may be present in the soil requires investigation to ensure that longevity is maximized.

Specimens of landfill soil stabilized with Mix 74 grout have been archived for future study. Some have been crushed and are currently being exposed to air for repeat TCLP tests. stabilization of soils contaminated with higher $\mathrm{Cr}$ levels should be performed to ensure that the grouts are capable of treating any 
high localized concentrations in the landfill.

\subsection{IN-8ITU CONTAINMENT OF STABILIZED CHROMIUM PLUME}

\subsection{Introduction}

Grout based subsurface containment barriers continued to be investigated in FY 94. Two types of barriers are considered. The first is for placement around the CWL chromium plume and assumes that the plume is stabilized either before or after barrier installation. Thus, it is assumed that the barrier will not be exposed to chromium leachants. The barriers will be placed in uncontaminated soil and therefore, do not require TCLP testing. The CWL barriers under consideration are either soil cement produced by in-situ mixing of soil and grout and monolithic grout produced by pumping grout into a cavity in the soil. The second type of barrier is for containment of tritiated water at the MWL and this is dealt with in section 6.0 .

Several aspects of subsurface barriers for the CWL were examined. Work on saturated permeability of cracked barriers and the effect of fibre reinforcement initiated in FY 93 was continued and completed. Further details of this work are available in the FY 93 Annual Report. Core samples from the FY 93 permeation grouting field trials were tested for strength and permeability. Jet grouting field trials were conducted at SNL. Addition of slag to grouts for subsurface barriers was also investigated. Worst case scenario tests were conducted to evaluate the consequences if the chromium is not stabilized.

\subsection{Experimental}

\subsubsection{Materials}

The materials used for the CWL barriers are the same as those described in Section 2.2.1, except for Mix 70 which contained sand. Mix 70 is intended for a monolithic grout barrier produced by replacing soil with grout. The other grouts are intended for insitu mixing with soil. Bentonite was added to prevent settling of sand and cement. In practice, if the grouts are mixed in a high shear mixer and pumped directly after mixing bentonite may be reduced. The mix proportions of the grouts are presented in Table 10. The letters "f" and " $c$ " refer to fine and coarse grades of sand respectively and are described further in the FY 93 Annual Report. 
Table 10. Mix Proportions of CwL Barrier Grouts

\begin{tabular}{||c|c|c|c|c|c|c|}
\hline $\begin{array}{c}\text { Mix } \\
\text { No. }\end{array}$ & $\begin{array}{c}\text { Cement } \\
\left(\mathrm{kg} / \mathrm{m}^{3}\right)\end{array}$ & $\begin{array}{c}\text { Slag } \\
\left(\mathrm{kg} / \mathrm{m}^{3}\right)\end{array}$ & $\begin{array}{c}\text { Sand } \\
\left(\mathrm{kg} / \mathrm{m}^{3}\right)\end{array}$ & $\begin{array}{c}\text { Water } \\
\left(\mathrm{kg} / \mathrm{m}^{3}\right)\end{array}$ & $\begin{array}{c}\text { Bentonite } \\
\left(\mathrm{kg} / \mathrm{m}^{3}\right)\end{array}$ & $\mathrm{SP}\left(1 / \mathrm{m}^{3}\right)$ \\
\hline $47-1$ & 1221 & 0 & 0 & 586 & 11.1 & 24.4 \\
\hline $47-2$ & 948 & 0 & 0 & 679 & 13.3 & 19.0 \\
\hline $74-1$ & 722 & 481 & 0 & 577 & 10.9 & 24.1 \\
\hline $74-2$ & 556 & 370 & 0 & 667 & 13.0 & 18.5 \\
\hline $74-5$ & 338 & 225 & 0 & 788 & 15.2 & 11.3 \\
\hline 70 & 769 & 0 & $\begin{array}{c}538(\mathrm{C}) \\
384\end{array}$ & 384 & 19.2 & 15.4 \\
\hline
\end{tabular}

The mix proportions of the soil cements produced by mixing grouts with dry, uncontaminated site soil are presented in Table 11.

Table 11. Mix Proportions of CWL soil Cement Barriers

\begin{tabular}{|c|c|c|c|c|c|c|}
\hline $\begin{array}{c}\text { Mix } \\
\text { No. }\end{array}$ & $\begin{array}{c}\text { Cement } \\
\left(\mathrm{kg} / \mathrm{m}^{3}\right)\end{array}$ & $\begin{array}{c}\text { Slag } \\
\left(\mathrm{kg} / \mathrm{m}^{3}\right)\end{array}$ & $\begin{array}{c}\text { Water } \\
\left(\mathrm{kg} / \mathrm{m}^{3}\right)\end{array}$ & $\begin{array}{c}\text { Bentonite } \\
\left(\mathrm{kg} / \mathrm{m}^{3}\right)\end{array}$ & $\begin{array}{c}\mathrm{SP} \\
\left(1 / \mathrm{m}^{3}\right)\end{array}$ & $\begin{array}{c}\text { Soil } \\
\left(\mathrm{kg} / \mathrm{m}^{3}\right)\end{array}$ \\
\hline $47 \mathrm{S1}$ & 816 & 0 & 391 & 6.5 & 16.3 & 816 \\
\hline $47 \mathrm{~S} 2$ & 537 & 0 & 388 & 7.7 & 10.7 & 1075 \\
\hline $74 S 1$ & 490 & 326 & 391 & 6.5 & 16.3 & 816 \\
\hline $74 S 2$ & 322 & 215 & 388 & 7.7 & 10.7 & 1075 \\
\hline 7455 & 161 & 107 & 376 & 7.4 & 5.4 & 1342 \\
\hline
\end{tabular}

Fibres were added to Mixes $47 \mathrm{~S} 1,47 \mathrm{~S} 2$ and 70 in a continuation of work from FY 93. Polypropylene collated fibrillated and monofilament fibres supplied by Forta Corporation were used. Both types of fibres were $19 \mathrm{~mm}$ in length. The collated fibrillated bundles open during mixing to form a three-dimensional network. The fibre network has improved mechanical bonding under tension as compared with monofilament fibres due to stress transfer throughout the fibrils, rather than solely at the fibre/matrix interface. The volume fraction of fibres was $0.2 \%$. Fibrillated fibre reinforced mixes are denoted by the suffix "0.2F" and monofilament fibres are denoted by "0.2MF".

\subsubsection{Specimen Preparation}

Neat cement grouts and soil cements were mixed in a planetary 
mixer as described in section 2.2.2. The sanded grout (70) was also mixed in a planetary mixer with sand being added last. Fibres were added to grouts after cement and any sand were mixed. The fibres were added in increments in an attempt to prevent clumping and mixed for 2 minutes. Fibrillated fibres tended to clump and tangle during mixing. Less mixing problems were encountered with the monofilament fibres.

Fibre reinforced soil cements were prepared by adding the fibre reinforced grout to the soil and mixing. The volume fraction of fibres was based on the soil cement volume. Monofilament fibres were used with 4752 , and both fibre types were used with 4751 and 70.

\section{2 .3 Curing}

The two types of curing, wet and soil, as described in section 2.2.3, were used for the barrier materials. Strength and permeability tests were performed on the 74 series of soil cements cured for 28 days in water. The same soil cements were tested for permeability after three months soil curing. Permeability was measured on plain and fibre reinforced $4751-5$ and 70 after four months soil curing. The results of wet cured properties for 4751-5 and 70 are reported in the FY 93 Annual Report.

\subsubsection{Unhardened Grout Properties}

The rheological properties and specific gravities of the 47 series and 70 grouts are described in the FY 93 Annual Report and the properties of the 74 series are described in section 2.3 .1 above.

\subsubsection{Permeability coefficient}

The water permeability coefficient (hydraulic conductivity) of the 47 and 74 series of soil cements and Mix 70 under saturated conditions was measured in a flexible wall triaxial cell permeameter on specimens $75 \mathrm{~mm}$ diameter and $105 \mathrm{~mm}$ long. The permeant was de-aired tap water. The applied pressure gradient was $207 \mathrm{kPa}$ and the confining pressure was $414 \mathrm{kPa}$. The chosen value of confining pressure was based on the maximum bearing pressure of interest. Three specimens per batch were tested and all specimens were saturated prior to measurement. Measurements conducted over pressure gradients from 69 to $207 \mathrm{kPa}$ on cracked and uncracked specimens indicated that Darcy's Law of flow through porous materials was applicable.

The effect of confining pressure on measured permeability for cracked specimens was also determined at 310,345 and $414 \mathrm{kPa}$.

In the first series of tests on plain and fibre reinforced grouts and soil cements conducted in FY 93, the specimens were 
cured in water for 28 days. Permeability coefficient was measured and the specimens were then subjected to 23 wet-dry cycles before re-saturation and re-measurement. The cycles consisted of submersion in water at $25^{\circ} \mathrm{C}$ for 5 hours followed by drying in air at $25^{\circ} \mathrm{C}$ and relative humidity of $40-50 \%$ for 43 hours.

In FY 94 permeability coefficient before and after drying in air at $25^{\circ} \mathrm{C}$ and $40-50 \%$ relative humidity for three months was measured on the plain and fibre reinforced 47 series of soil cements and the 70 grout. Field curing conditions were simulated by burying the specimens in site soil for four months. Saturation was performed before measurement of permeability coefficient. The purpose of the drying tests was to eliminate the crack healing that arises during wet-dry cycling when calcium hydroxide leaches out of the grout or soil cement and reacts with carbon dioxide to form calcium carbonate. This enabled comparison of material performance under conditions that do not favour crack healing.

The permeability coefficient of 74S1-5 was measured after 28 days wet curing and then after 12 wet-dry cycles and re-saturation. Permeability after 84 days soil curing and saturation was also measured on 74S1-5.

\subsubsection{Unconfined Compressive Strength}

Compressive strength measurements were performed on the CWL barrier materials using the same method described in section 2.2.9. The strength properties of $47 \mathrm{~S} 1-5$ and 70 are described in the FY 93 Annual Report. Strength of 74S1-5 was measured after 28 days wet curing.

\subsubsection{Chromium Diffusion Tests}

The diffusion of chromium through discs of grout and soil cement was investigated. The purpose of the experiment was to simulate a worst case scenario where unstabilized chromium within the plume is mobile and contacts the barrier. The response of the barrier material to direct contact with chromium was studied. Chromic acid solution with a concentration of $3.8 \times 10^{-3} \mathrm{M}(200 \mathrm{ppm}$ Cr(VI) with a $\mathrm{pH}$ of 2.51 was used to accelerate the aggressiveness of the test. Chromic acid is known to be deleterious to cementitious materials (Biczok, 1972). Two soil cements (74SI and 7452) were tested.

The diffusion cell used is shown in Figure 11. Two chambers constructed from uPVC pipe were separated by a disc of grout or soil cement. The chambers had polymethylmethacrylate caps with screw in plugs to enable filling and sampling. The discs had a diameter of $56 \mathrm{~mm}$ and a thickness of approximately 10-11 $\mathrm{mm}$. Specimens were cast in $76 \mathrm{~mm}$ diameter cylinders and trimmed to fit the cell. The actual dimensions of the disc were measured before 


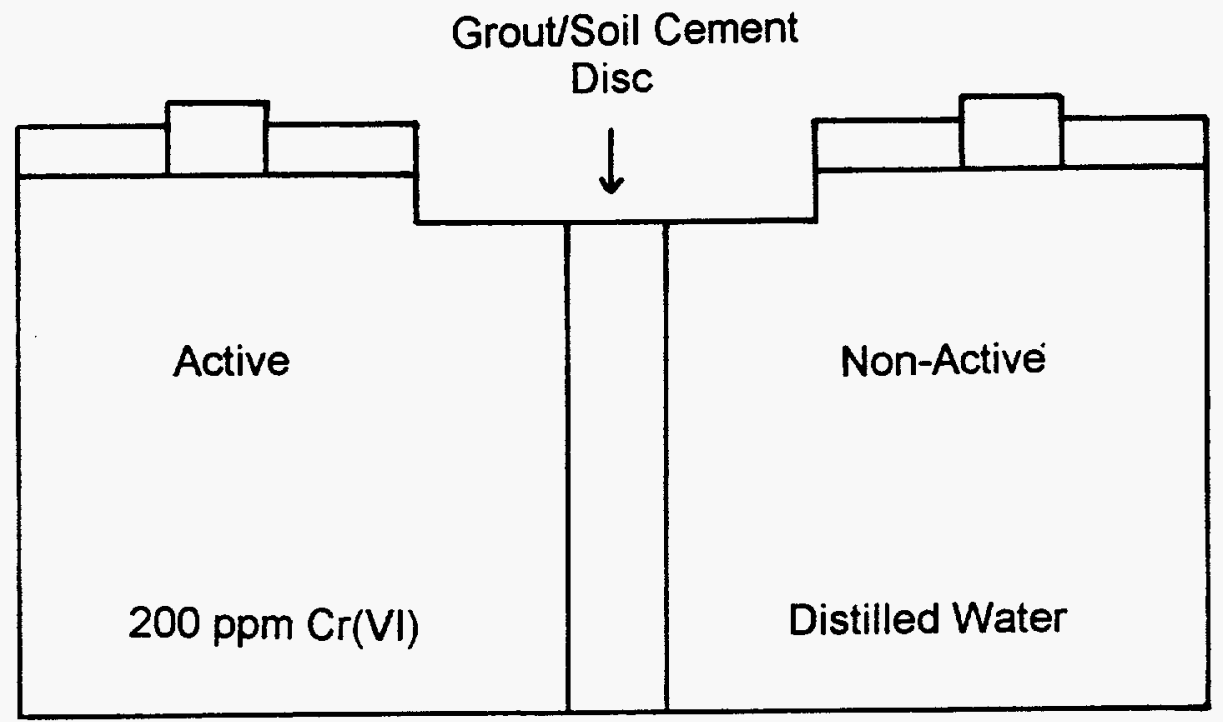

Figure 11. Schematic diagram of diffusion cell used for chromium and tritium diffusion experiments. 
placement in the cell. The joint between the discs and cell walls were sealed with a silicone rubber compound. One side (active) of the diffusion cell contained $375 \mathrm{ml}$ of the chromic acid solution and the other side (non active) contained $375 \mathrm{ml}$ of distilled water. Samples of $1 \mathrm{ml}$ were withdrawn from the non-active side at periodic intervals for $\mathrm{Cr}$ analysis by atomic absorption spectrophotometry. The cell contents were stirred before sampling.

\subsubsection{Permeation Grouting}

The details of the permeation grouting field trials at SNL in FY 93 are presumably available from SNL. As discussed in the FY 93 Annual Report, BNL believed that permeation grouting would have a low probability of forming a continuous barrier in a controlled and predictable manner due to the fine particle size of the site soil. However, a microfine cement grout was used in field trials. The mix proportions of this grout are given in Table 12 and the unhardened properties are given in Table 13. The flow time was measured using an ASTM C 939 flow cone, and should not be confused with a Marsh funnel. A pulverized grout was also used in the field trials, but was not part of the BNL program, nor were other materials such as sodium silicate and wax.

Table 12. Mix Proportions of Microfine cement Grout

\begin{tabular}{|c|c|c|c|}
\hline $\begin{array}{c}\text { Microfine } \\
\text { Cement }\left(\mathrm{kg} / \mathrm{m}^{3}\right)\end{array}$ & Water $\left(\mathrm{kg} / \mathrm{m}^{3}\right)$ & $\begin{array}{c}\text { Bentonite } \\
\left(\mathrm{kg} / \mathrm{m}^{3}\right)\end{array}$ & SP $\left(1 / \mathrm{m}^{3}\right)$ \\
\hline 717 & 717 & 14.4 & 14.3 \\
\hline
\end{tabular}

Table 13. Properties of Unhardened Microfine Cement Grout

\begin{tabular}{|c|c|c|}
\hline Viscosity (CP) & ASTM Flow Time (s) & specific Gravity \\
\hline 9 & 9.4 & 1.47 \\
\hline
\end{tabular}

Core samples of the grouted soil were shipped to BNL in November, 1993. The age of the specimens was approximately three months and the core diameters were $84 \mathrm{~mm}$. The cores were soaked in water for compressive strength testing and saturated in water for permeability measurements.

\subsection{Results and Discussion}

\subsubsection{Permeability Coefficient of slag Modified soil cements}

The permeability coefficients for the 28 day wet cured and the 84 day soil cured soil cements prepared from Mix 74 are given in Table 14. The mean value and one standard deviation are indicated. 
The results are also shown graphically in Figures 12 and 13 .

Table 14. Permeability Coefficients of slag Modified soil cements

\begin{tabular}{|c|c|c|}
\hline Mix & $\begin{array}{c}28 \text { Day Wet Cured } \\
\text { Permeability }\left(\times 10^{-10} \mathrm{~cm} / \mathrm{s}\right)\end{array}$ & $\begin{array}{c}84 \text { Day Soil Cured } \\
\text { Permeability }\left(\times 10^{-10} \mathrm{~cm} / \mathrm{s}\right)\end{array}$ \\
\hline 7451 & $1.7 \pm 0.1$ & $5.7 \pm 0.8$ \\
\hline 7452 & $3.0 \pm 0.9$ & $21 \pm 5$ \\
\hline 7455 & $12 \pm 1.0$ & $26 \pm 8$ \\
\hline
\end{tabular}

The results can be compared with those for the soil cements without slag (47 series) measured with the same instrument in FY 93. The permeability coefficients of 28 day wet cured 4751 and 4752 were $6.0 \times 10^{-10} \pm 0.5 \times 10^{-10} \mathrm{~cm} / \mathrm{s}$ and $7.5 \times 10^{-10} \pm 0.8 \times 10^{-10} \mathrm{~cm} / \mathrm{s}$, respectively. This indicates that slag improved the impermeability at s/C ratios of 1 and 2 for wet curing conditions. When the soil cements were cured by burial in soil for 84 days the permeabilities were higher, but remained below the $10^{-7} \mathrm{~cm} / \mathrm{s}$. limit. The permeabilities were similar for $\mathrm{s} / \mathrm{c}=2$ and 5 . The increase in permeability when the materials are cured in soil is due to reduced hydration of cement.

The permeability coefficients of the wet cured specimens after 12 wet-dry cycles are presented in Table 15 and compared with initial values graphically in Figure 14.

Table 15. Permeability coefficients of wet cured slag Modified soil Cements After wet-Dry Cycles

\begin{tabular}{|c|c|}
\hline Mix & $\begin{array}{c}\text { Permeability After } 12 \text { Wet-Dry Cycles } \\
(\mathrm{cm} / \mathrm{s})\end{array}$ \\
\hline 7451 & $3.3 \times 10^{-9} \pm 1 \times 10^{-9}$ \\
\hline 7452 & $1.0 \times 10^{-8} \pm 2 \times 10^{-9}$ \\
\hline 7455 & $2.8 \times 10^{-6} \pm 4 \times 10^{-7}$ \\
\hline
\end{tabular}

The standard deviation of the permeability coefficients after the specimens were subjected to wet-dry cycles is high and this is due to heterogeneity of cracking. The soil cements with $\mathrm{s} / \mathrm{c}=1$ and 2 remained below the EPA permeability limit of $10^{-7} \mathrm{~cm} / \mathrm{s}$. Although the laboratory testing conditions do not replicate exactly the field conditions to which the barriers will be exposed, the susceptibility of Mix 7455 to formation of permeable cracks limits its usefulness as a barrier material. Furthermore, after testing the specimens of 7455 were maintained in air and developed surface deterioration in the form of flaking after 4 months. Therefore, 


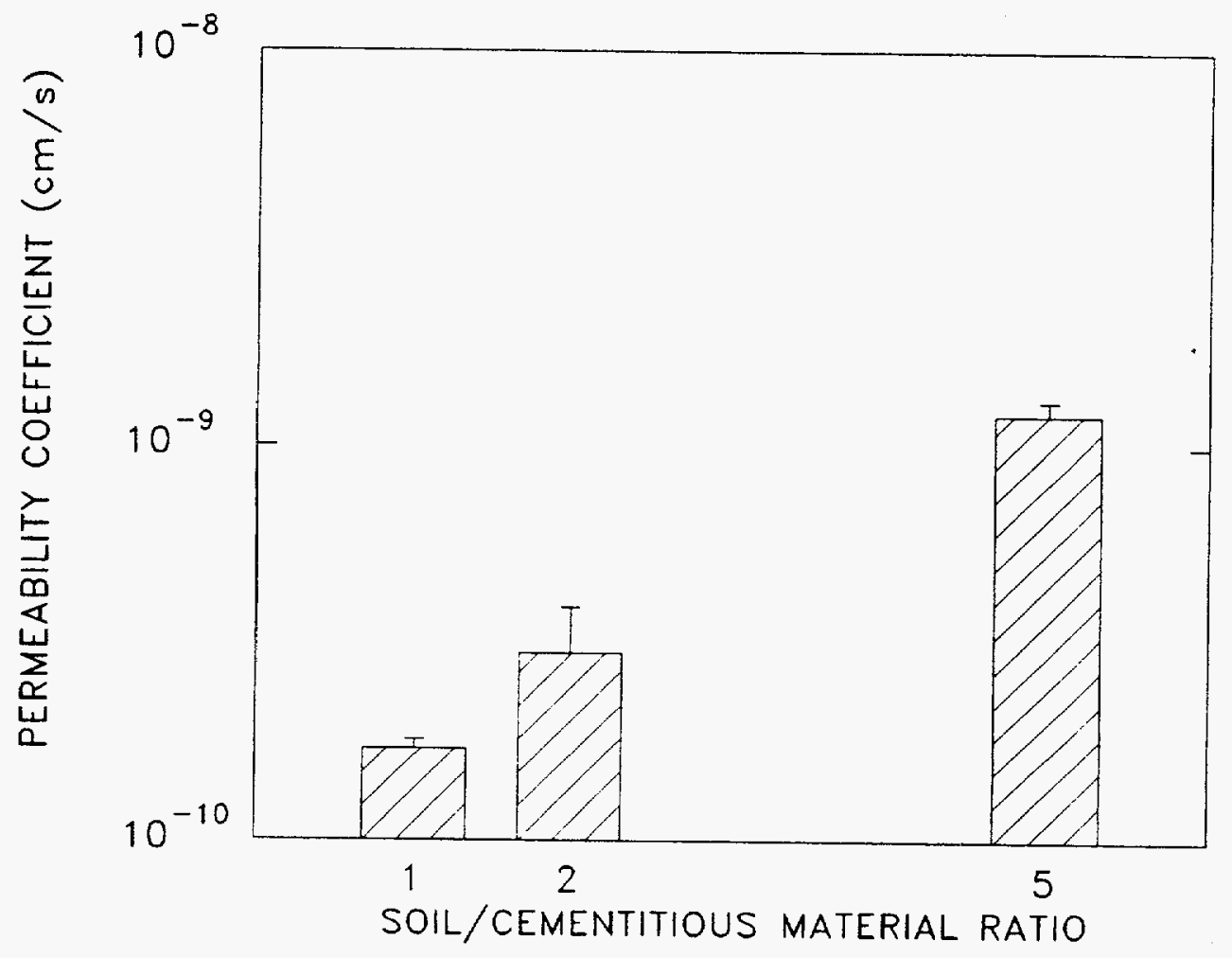

Figure 12. Permeability coefficient of slag modified soil cements after 28 days wet curing. 


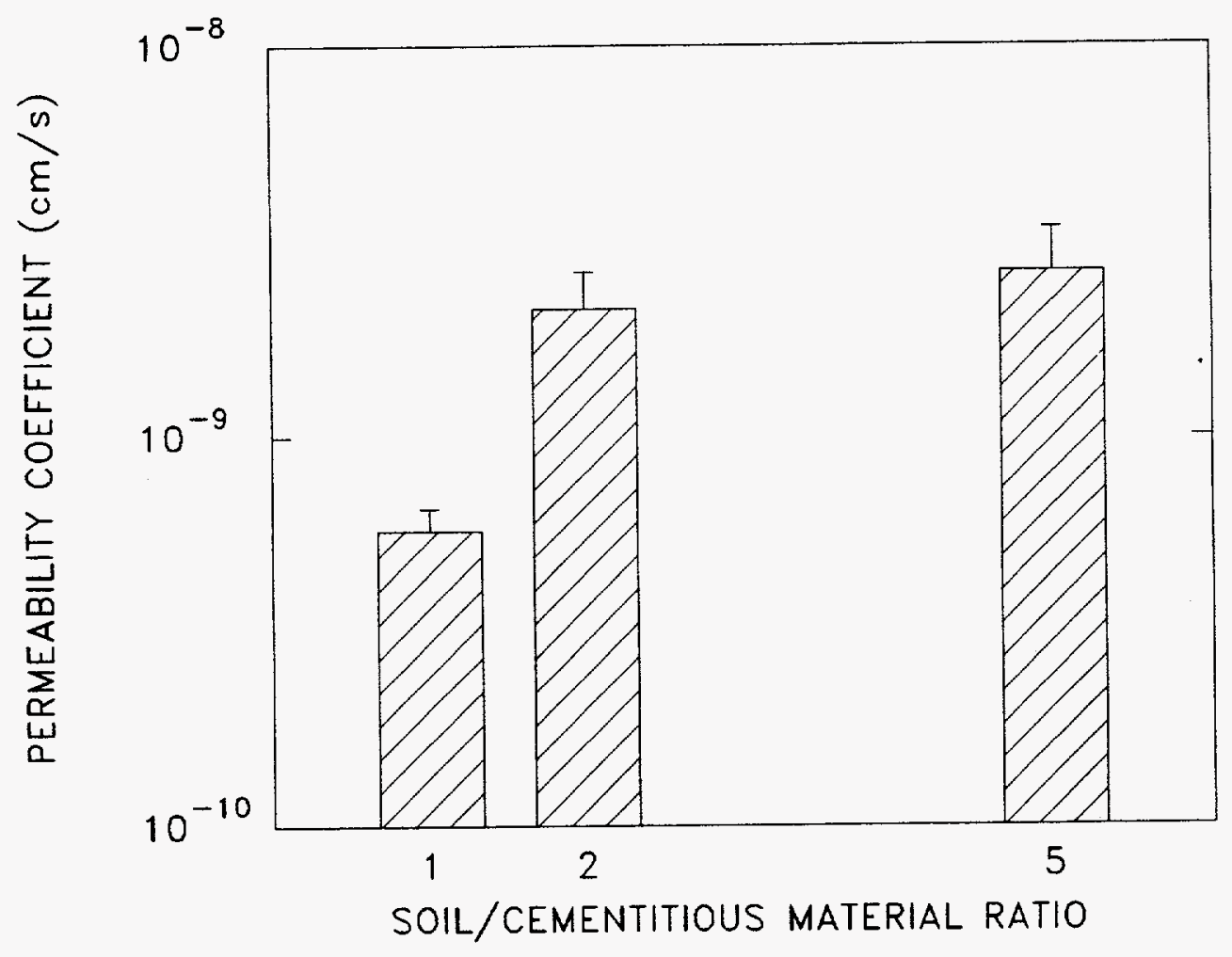

Figure 13. Permeability coefficient of slag modified soil cements after 84 days soil curing. 
this mix with its high $s / c$ and $w / C$ values is not recommended for the CWL barriers.

\subsubsection{Permeability Coefficient of soil Cured Grout Before and After Drying}

The permeability coefficients of the plain and fibre reinforced versions of Mix 70 after four months curing in soil and saturation are shown in Table 16 and Figure 15 . The codes $0.2 \mathrm{~F}$ and $0.2 \mathrm{MF}$ refer to $0.2 \%$ fibrillated fibres and $0.2 \%$ monofilament fibres respectively. The permeabilities for the same specimens after drying in air for three months and re-saturation are also given.

Table 16. Permeability Coefficients of Plain and Fibre Reinforced Grout Before and After Drying

\begin{tabular}{|c|c|c|}
\hline Mix & $\begin{array}{c}112 \text { Day Soil Cured } \\
\text { Permeability }\left(\times 10^{-10}\right. \\
\text { Cm/s })\end{array}$ & $\begin{array}{c}\text { Permeability After } \\
\text { Drying and Re- } \\
\text { saturation }\left(\times 10^{-10} \mathrm{~cm} / \mathrm{s}\right)\end{array}$ \\
\hline 70 & $2.4 \pm 0.1$ & $3.6 \pm 1.2$ \\
\hline $700.2 \mathrm{~F}$ & $5.8 \pm 0.3$ & $8.8 \pm 0.8$ \\
\hline $700.2 \mathrm{MF}$ & $2.5 \pm 0.6$ & $8.5 \pm 2.0$ \\
\hline
\end{tabular}

The extent of microcracking on the dried specimens appeared less than that for the wet-dry specimens tested in FY 93 (see Annual Report) and crack healing did not occur. After drying and re-saturation, the permeability coefficients of the fibre reinforced grouts are greater than those for the plain grouts. For the wet cured and wet-dry cycle specimens reported in FY 93 , the permeability coefficient of the monofilament fibre reinforced grout ( $700.2 \mathrm{MF}$ ) was significantly higher than the plain grout $\left(9.2 \times 10^{-9}\right.$ $\mathrm{cm} / \mathrm{s}$ compared with $1.4 \times 10^{-9} \mathrm{~cm} / \mathrm{s}$ ).

The initial permeability coefficient for the grout with $0.2 \%$ fibrillated fibres is higher than the plain and monofilament fibre reinforced materials and this is possibly due to batch variation. The higher initial permeability coefficient of the fibrillated fibre reinforced grout may obscure the crack resistance if permeabilities are compared on absolute terms. The relative increases were 50\%, 52\% and $240 \%$ for the plain, $0.2 \%$ fibrillated fibre and $0.2 \%$ monofilament fibre reinforced mixes, respectively. Therefore, the addition of monofilament fibres to the grout results in reduced performance for the $\mathrm{mix}$ and conditions studied. 


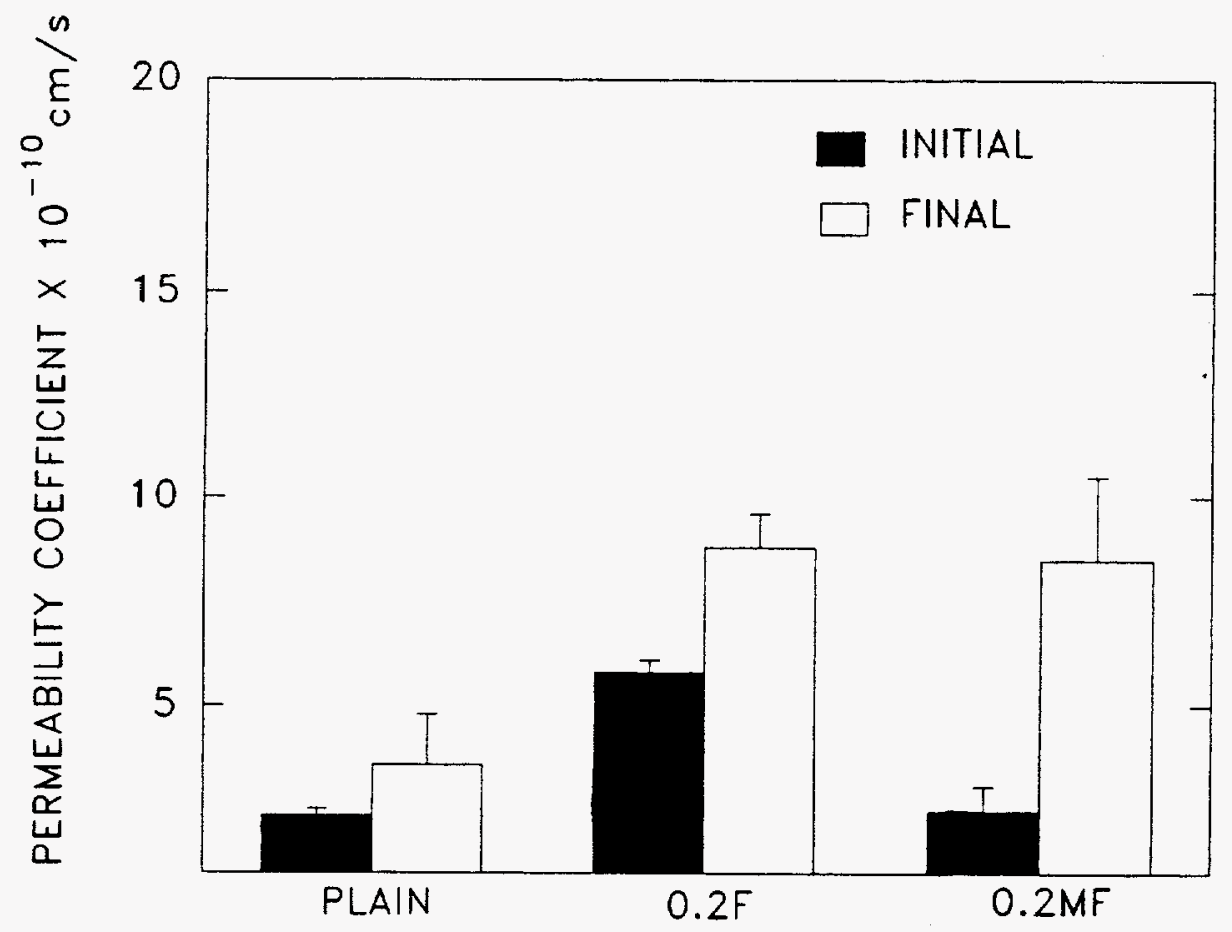

Figure 15. Effect of 0.27 Fibrillated $(0.2 \mathrm{~F})$ and $0.2 \%$ Monofilament Fibres (0.2MF) on Permeability coefficient of soil cured Grout Before and After Drying and Re-saturation. 


\subsubsection{Permeability coefficient of soil cured soil cements Before and After Drying}

Table 17 and Figure 16 shows the permeability coefficient before and after drying and re-saturation for the soil cured soil cements. In Figure $16 \mathrm{~S} 1$ and $\mathrm{S} 2$ refer to $47 \mathrm{~S} 1$ and $47 \mathrm{S2}$, respectively.

Table 17. Permeability Coefficient of Plain and Fibre Reinforced soil Cements Before and After Drying

\begin{tabular}{|c|c|c||}
\hline Mix & $\begin{array}{c}112 \text { Day Soil Cured } \\
\text { Permeability }\left(\times 10^{-10}\right. \\
\mathrm{cm} / \mathrm{s})\end{array}$ & $\begin{array}{c}\text { Permeability After } \\
\text { Drying and Re- } \\
\text { saturation }\left(\times 10^{-10} \mathrm{~cm} / \mathrm{s}\right)\end{array}$ \\
\hline $47 \mathrm{S1}$ & $2.4 \pm 0.2$ & $3.5 \pm 1.0$ \\
\hline $47 \mathrm{S1} 0.2 \mathrm{~F}$ & $2.1 \pm 0.7$ & $3.5 \pm 1.0$ \\
\hline $\begin{array}{c}47 \mathrm{~S} 1 \\
0.2 \mathrm{MF}\end{array}$ & $2.8 \pm 0.3$ & $18 \pm .3 .0$ \\
\hline $47 \mathrm{S2}$ & $16 \pm 1.1$ & $50 \pm 1.0$ \\
\hline $\begin{array}{c}47 \mathrm{S2} \\
0.2 \mathrm{MF}\end{array}$ & $23 \pm 1.0$ & $150 \pm 30$ \\
\hline
\end{tabular}

The four month soil cured permeabilities were all low, indicating suitability for barrier materials if the same properties can be achieved in the field. The initial values of permeability show that 4752 has greater sensitivity to curing conditions than 47S1. After drying and re-saturation the higher permeability of $47 \mathrm{~S} 2$ signifies reduced crack resistance compared with $47 \mathrm{SI}$. It is proposed that soil curing followed by wet-dry cycling would result in a higher final permeability coefficient than $5.0 \times 10^{-9} \mathrm{~cm} / \mathrm{s}$ since wet-dry cycles are more aggressive than continued drying. Thus, superior impermeability under such exposure conditions would require use of a tough material which is less sensitive to inadequate curing conditions. The CWL conditions are not expected to be as aggressive as those encountered in repeated wetting and drying used in the laboratory studies.

For 4751 , the final permeability coefficient after soil curing followed by drying was not altered significantly when $0.2 \%$ fibrillated fibres were added and the mean value for both the plain and fibrillated fibre mixes was $3.5 \times 10^{-10} \mathrm{~cm} / \mathrm{s}$. Addition of monofilament fibres to $47 \mathrm{Sl}$ resulted in a steep increase in final mean permeability coefficient $\left(1.8 \times 10^{-9} \mathrm{~cm} / \mathrm{s}\right)$ as compared with the plain and fibrillated fibre reinforced mixes. Since all of the mixes with $s / c=1$ had similar magnitudes of initial permeability, 


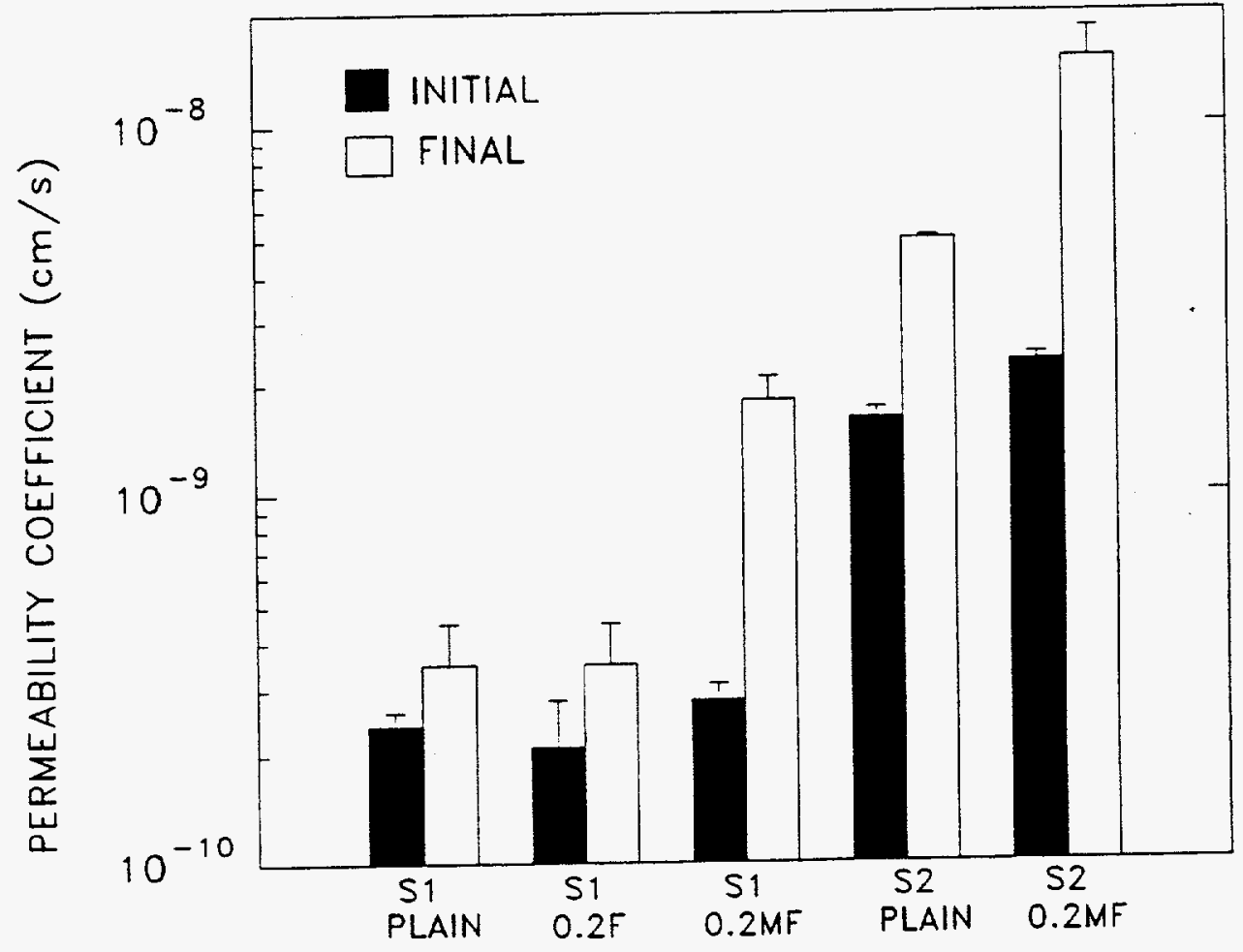

Figure 16. Effect of 0.28 Fibrillated $(0.2 \mathrm{~F})$ and 0.28 Monofilament Fibres (0.2MF) on Permeability coefficient of soil cured soil Cement Before and After Drying and Re-saturation. 
the increased final value of the fibre reinforced material cannot be attributed to batch variation.

Addition of 0.28 monofilament fibres to 4752 resulted in a final mean permeability coefficient of $1.5 \times 10^{-8} \mathrm{~cm} / \mathrm{s}$ compared with $5.0 \times 10^{-9} \mathrm{~cm} / \mathrm{s}$ for the plain version. The final permeability coefficients of the monofilament reinforced soil cements were significantly higher than those for the unreinforced or fibrillated reinforced versions.

\subsubsection{Effect of Confining Pressure}

The relationship between confining pressure and permeability coefficient shown in Figure 17 indicates that the confining pressure applied in the permeameter tends to close microcracks. This phenomenon has also been reported by Daniel et al. (1985). The implication is that the saturated flow permeability coefficients of the microcracked materials would be higher for unconfined conditions. Thus, the overburden pressure to which the barrier is exposed will influence the permeability when microcracks are present. Since the confining pressure was kept constant for all of the test results presented in Tables 16 and 17 , the relative effect of crack closing should be similar for all materials.

\section{3 .5 Compressive strength}

The compressive strengths of plain and fibre reinforced versions of $47 \mathrm{S1}, 47 \mathrm{S2}$ and 70 were presented in the FY 93 Annual Report. The 28 day wet cured strengths of the slag modified soil cements are presented in Table 18 and Figure 18. Comparison between Table 18 and Table 7 shows that the strengths are similar for the $408 \mathrm{slag} / 60 \%$ cement treated soils with or without chromium. Therefore, $200 \mathrm{ppm}$ Cr(III) does not appear to have a significant effect on compressive strength.

Table 18. Compressive strength of slag Modified soil cements

\begin{tabular}{|c|c|}
\hline Mix No. & 28 Day Wet Cured Compressive Strength \\
(MPa)
\end{tabular}

3.3.6 Chromium Diffusion

At the time of writing, no chromium has been detected in the non-active side of the soil cement diffusion cells after 90 days. 

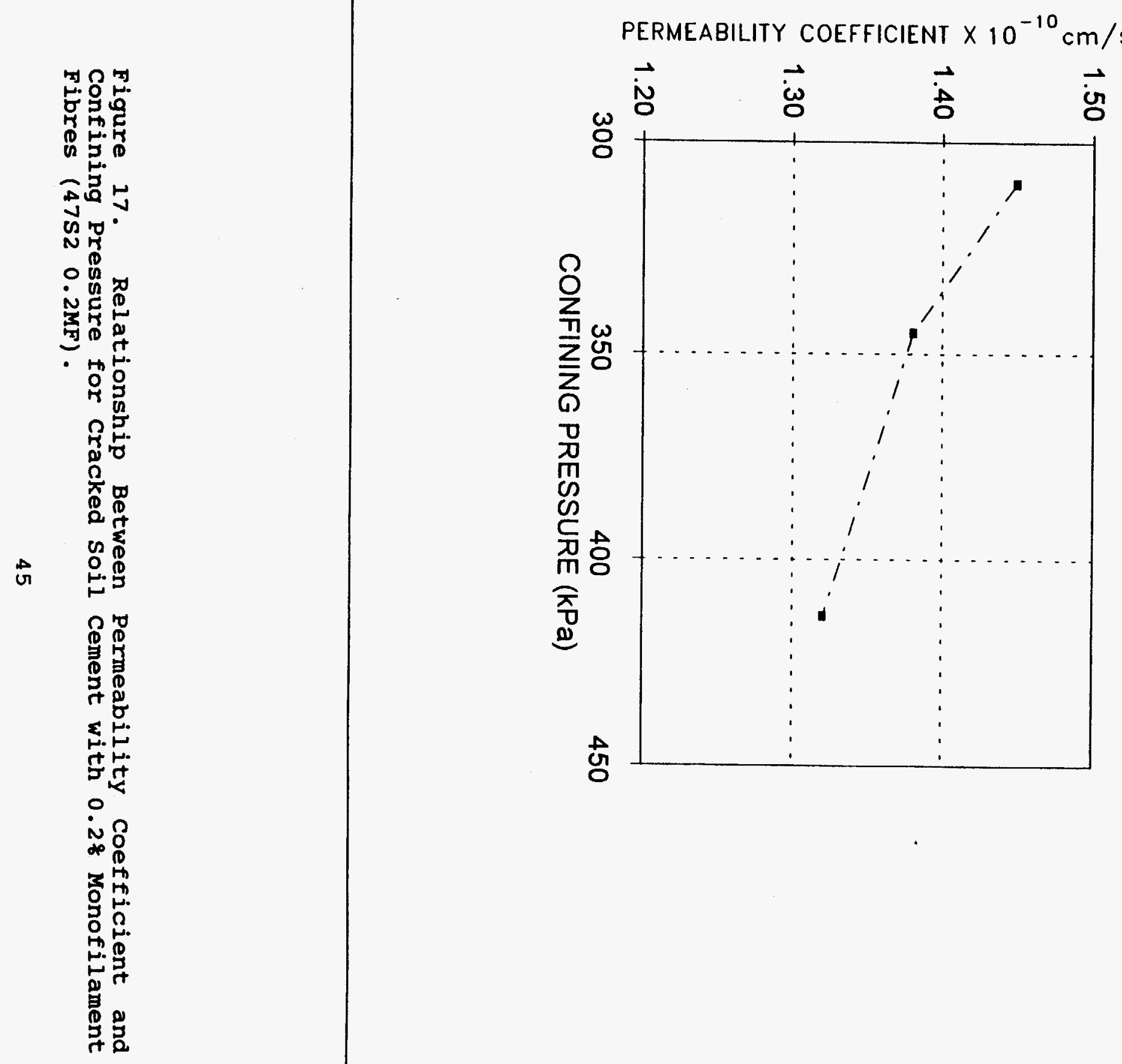


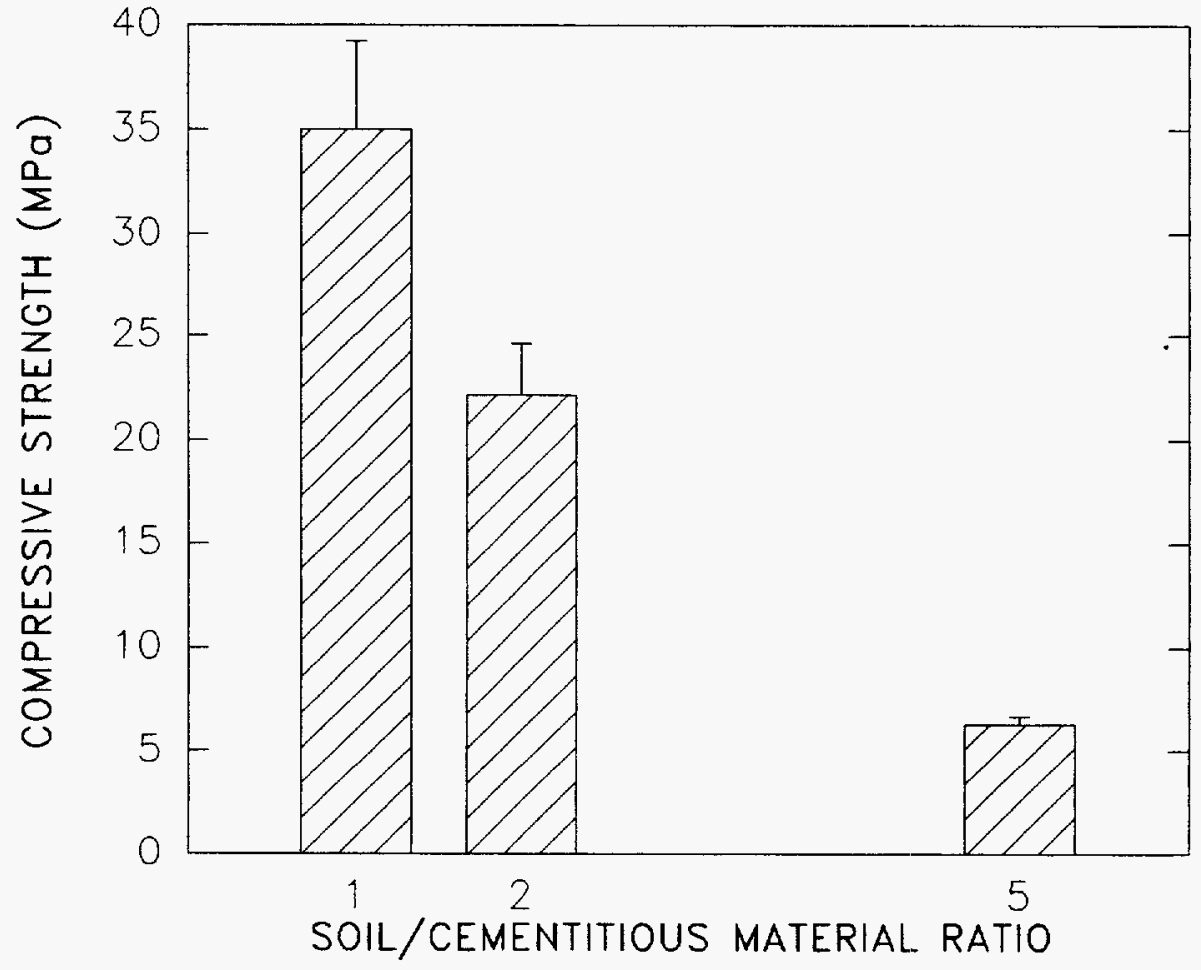

Figure 18. Compressive strength versus soil/cementitious material ratio for slag modified soil cements after 28 days wet curing. 


\subsubsection{Permeation Grouting cores}

six core samples from the permeation grouting field trials at SNL were received. Five of the cores were soil grouted with the pulverized cement and the sixth was of the soil grouted with microfine cement. Examination of the cores showed that the grout successfully penetrated in areas where the soil had a gravelly texture. The soil was significantly more coarse than samples shipped to BNL. Areas of finer soil in the cores were not penetrated by either grout. The uncemented soil crumbled during cutting of the samples. The cores exhibited coarse air voids and finer voids within the grout phase. For the small core of microfine cement treated soil, it was evident that the grout had caused fracture of the soil, and that the grout penetrated the fractures in preference to the fine soil. Thus, the grout permeation appears to be inhomogeneous.

Two of the pulverized grout cores were long enough for compressive strength tests. The measured strengths were 28 and 33 $\mathrm{MPa}$, which is relatively high and more than adequate for the purpose. The density of the samples was around $2300 \mathrm{~kg} / \mathrm{m}^{3}$. The high strength was attributed to the high grout content of the cores. Areas where grout does not penetrate the soil are expected to have lower strengths.

Permeability tests on cores were performed. The permeability of two cores containing the pulverized cement grout were $5.3 \times 10^{-8}$ and $2.7 \times 10^{-9} \mathrm{~cm} / \mathrm{s}$. The one core of microfine cement grout treated soil had a permeability of $8.4 \times 10^{-7} \mathrm{~cm} / \mathrm{s}$. While it is not possible to draw definitive conclusions from the small numbers of samples obtained from a grouted cobble layer, it is evident that the microfine cement grout does not meet the impermeability requirements for subsurface barriers. This concurs with the visual observations of incompletely grouted soil within the sample. The permeability of the soil grouted with pulverized cement was reasonably low but is meaningless if the grout does not penetrate in a uniform and predictable manner. The results also suggest that alternative placement techniques such as jet grouting and soil mixing using the materials developed in this program must be field tested.

\subsubsection{General Discussion of In-situ Containment of Chromium Plume}

It is recognized that mixing and exposure conditions in the field will vary somewhat from those used in these laboratory experiments. Grouts with partial replacement of cement with slag appear suitable for producing soil cement barriers. Soil/cementitious ratio and water/cementitious material ratio must be kept as low as practical to enhance performance. Addition of 
slag may also provide benefits of reduced heat generation and sulphate resistance as discussed in the section on stabilization, but this requires confirmation.

The practicality of placing fibre material reinforced barriers requires further investigation before use of fibres can be recommended. For simulated in-situ curing followed by drying in air, fibrillated fibres do not result in improvement of crack resistance and this may be due to reduced interfacial bond development associated with less extensive hydration. Monofilament fibres were detrimental to permeability when microcracks formed in soil cured materials. It is proposed that the observed increased final permeability coefficient associated with monofilament fibre reinforced materials is due to high conductivity paths developed when interconnected microcracks form between fibres and along fibre/matrix interfaces. The failed interfacial surface length is likely to be greater for monofilament than fibrillated fibre reinforced materials. This is because tensile stresses will tend to result in failure along the entire length of a monofilament strand, whereas stress transfer across fibrils will occur in fibrillated fibres and reduce the length of fibre disbondment.

For field conditions additional factors, such as the permeability of the soil surrounding the barriers and the saturation level of the barrier itself, also influence the criticality of cracks. These factors have been considered by Walton and seitz (1992). Cracks may be less catastrophic for an arid, unsaturated environment than for saturated conditions depending on water tension within cracks. Thus, flow through a cracked barrier in unsaturated conditions may be controlled by the permeability of the uncracked matrix. Conversely, flow through a saturated cracked barrier will be controlled by crack permeability. Hence, the results obtained for saturated flow on uncovered materials require some qualification before application to an unsaturated, backfilled environment. The presence of polypropylene/matrix fracture surfaces may complicate unsaturated flow due to altered surface tension as compared with matrix fracture flow paths.

\subsubsection{Recommendations for Future Work on In-Situ Containment of Chromium Plumes}

As was the case for the stabilized chromium contaminated soil, the CWL barrier materials should be tested for durability to sulphate attack and sulphur oxidizing bacteria. The chromium diffusion experiments will continue to be monitored until a diffusion coefficient can be calculated.

It is proposed to investigate the hydraulic behaviour of the CWL type subsurface barriers for unsaturated conditions. The permeability studies conducted to date on cracked and uncracked grout and soil cement barriers have been performed under saturated 
conditions. In both instances sufficiently low permeabilities have usually been measured. In practice, permeability coefficients are greater under saturated conditions than unsaturated, hence the obtained results provide a "worst-case scenario" for the typically arid conditions at SNL. However, if the barriers contain cracks flow will depend more significantly on saturation levels. For saturated conditions flow will occur through cracks in preference to the uncracked matrix, whereas the opposite will probably occur in unsaturated conditions and the impact of cracks on performance may be insignificant. Hence, the results for saturated permeability of microcracked barriers also represent an upper Iimit. By measuring the effect of cracking on flow for unsaturated conditions a better indication of the exact impact of cracks on barrier performance under the typical site conditions will be achieved.

Future work for CWL barrier field trials is discussed in section 4. Permeation grouting with cementitious materials is not recommended.

\subsection{JET GROUTING FIELD TRIALS}

The BNL component of the FY 94 jet grouting field trials at SNL was to provide a test plan, grout formulations and conduct measurements on core samples. The trials were initiated on 30 July, 1994 at an uncontaminated site close to the CWL.

In the original test plan dated 19 April, 1994 a total of four grouts were identified for test. Both columns and laminar panels were to be produced. The objective of investigating panels was to determine whether reduced wall thickness could be achieved in practice. The grouts consisted of an ordinary portland cement based material and a slag modified material, at two different water cement ratios. The mix proportions were similar to those for $47-1$, 47-2, 74-1 and 74-2, but had lower $w / c$ ratios.

It was stipulated in the original test plan that grout should be used as a drilling fluid in preference to water since drilling with water would effectively dilute the grout and change the w/c in an uncontrolled manner.

The target column diameter was $1.0 \mathrm{~m}$ and tests were necessary to determine what diameters could be achieved in the site conditions. The original desired column length was $5.0 \mathrm{~m}$. It was also planned to place adjoining columns so that the barrier continuity could be studied.

The extent of the field trials and the column heights were reduced from the original plan. The jet grouting was performed by the Westinghouse Hanford Company using Casagrande Jet 5 equipment. other grouts were evaluated at the same site, but these were not part of the BNL component. 
A major obstacle to the jet grouting trials was the absence of a suitable grout mixer. BNL had assumed that either a high shear or paddle grout mixer of suitable capacity would be available, since this is a standard and fundamental piece of equipment for grouting operations. Production of the type of high quality grout necessary for environmental remediation or other high performance applications requires an efficient mixer. Also, since the objective was to test the grouts under field conditions, a grout mixer of the type routinely used by the grouting industry was desired.

It was suggested to BNL by SNL and Westinghouse Hanford personnel conduction the trials that a concrete ready mix truck could be used for grout mixing. This suggestion was rejected for a variety of logistical reasons (e.g. change in grout fluid properties during transit, possible need for retarder) and practical reasons. Ready mix trucks are designed for mixing concrete containing coarse aggregate. It was believed that the neat cement grouts would separate into two components: a paste stuck to the barrel walls and a liquid comprised predominantly of water. On 28 and 29 July, 1994, work not related to the BNL component was conducted by Westinghouse Hanford using a grout comprising of 1 part cement to 1 part water by weight, mixed and transported to the site in a ready mix truck. It was observed that the grout was non-uniform, with lumps of cement paste and watery grout being ejected at different times. This type of ineffective mixing and poor quality grout is inappropriate for CWL barriers.

As a compromise, small scale mixing was improvised using a drill mixer in two 2001 containers. The mixed grout was then transferred to another 2001 drum and recirculated by a centrifugal pump. Houlsby (1990) describes this type of mixing as "relatively crude and is only tolerated on very low standard, cheap grouting". This should be kept in mind when evaluating the results of the jet grouting trials. Proper mixing would improve the properties of the grouts and grouted soil.

The mix proportions of the grouts used in the jet grouting field trials are presented in Table 19. The order of addition was water, bentonite, superplasticizer, cement and slag. The associated specific gravities, viscosities and Marsh and ASTM C 939 flow times of the laboratory grouts are given in Table 20 . Note that flow times were measured at ambient temperature of $28.5^{\circ} \mathrm{C}$ to simulate the expected high temperatures at the SNL site. 
Table 19. Mix Proportions of Grouts for Jet Grouting Field Trials

\begin{tabular}{|c|c|c|c|c|c|}
\hline Mix & $\begin{array}{c}\text { Cement } \\
\left(\mathrm{kg} / \mathrm{m}^{3}\right)\end{array}$ & $\begin{array}{c}\text { Slag } \\
\left(\mathrm{kg} / \mathrm{m}^{3}\right)\end{array}$ & $\begin{array}{c}\text { Water } \\
\left(\mathrm{kg} / \mathrm{m}^{3}\right)\end{array}$ & $\begin{array}{c}\text { Bentonite } \\
\left(\mathrm{kg} / \mathrm{m}^{3}\right)\end{array}$ & $\mathrm{SP}\left(1 / \mathrm{m}^{3}\right)$ \\
\hline $47-1 \mathrm{~A}$ & 1361 & 0 & 544 & 11 & 27 \\
\hline $47-2 \mathrm{~A}$ & 1083 & 0 & 628 & 12 & 22 \\
\hline $74-2 \mathrm{~A}$ & 642 & 428 & 621 & 12 & 21 \\
\hline
\end{tabular}

Table 20. Properties of Unhardened Grout Prepared in Laboratory

\begin{tabular}{|c|c|c|c|c|}
\hline Mix & Viscosity (CP) & $\begin{array}{c}\text { Marsh Flow } \\
\text { Time (s) } \\
28.5^{\circ} \mathrm{C}\end{array}$ & $\begin{array}{c}\text { ASTM Flow } \\
\text { Time (s) } \\
28.5{ }^{\circ} \mathrm{C}\end{array}$ & $\begin{array}{c}\text { Specific } \\
\text { Gravity }\end{array}$ \\
\hline 47-1A & 51 & 84.5 & 12.7 & 1.95 \\
\hline $47-2 \mathrm{~A}$ & 15 & 38.6 & 9.5 & 1.75 \\
\hline $74-2 \mathrm{~A}$ & 18 & 38.0 & 9.5 & 1.73 \\
\hline
\end{tabular}

The absence of a suitable capacity grout mixer reduced the volume of grout that could be mixed and stored. Therefore, it was not practical to use grout as a drilling fluid. This was a serious problem with strong implications. Holes for the columns and panels were predrilled using water as drilling fluid. During the time between predrilling and grouting, water seeped into the surrounding soil. This would increase the effective water content of the soil cement, and act to increase permeability compared with material without the residual water. The holes were predrilled to a depth of $1.5 \mathrm{~m}$. The bit was reinserted to the hole and grouting was conducted during withdrawal over $0.9 \mathrm{~m}$. For the two panels the holes were drilled at $0.46 \mathrm{~m}$ centres and the panels were grouted successively.

The properties of the field mixed grouts and the jet grouting parameters are given in Table 21 . In each case two nozzles with $2.0 \mathrm{~mm}$ diameter were used. 
Table 21. Jet Grouting Parameters and Grout Properties

\begin{tabular}{|c|c|c|c|c|c|c||}
\hline Mix & $\begin{array}{c}\text { Specific } \\
\text { Gravity }\end{array}$ & $\begin{array}{c}\text { ASTM } \\
\text { Flow } \\
\text { Time } \\
(\mathrm{s})\end{array}$ & $\begin{array}{c}\text { Grout } \\
\text { Temp. } \\
\left({ }^{\circ} \mathrm{C}\right)\end{array}$ & $\begin{array}{c}\text { Withdrawal } \\
\text { Rate } \\
(\mathrm{s} / 5 \mathrm{~cm} \\
\text { step) }\end{array}$ & $\begin{array}{c}\text { Pressure } \\
\text { (bar) }\end{array}$ & $\begin{array}{c}\text { Revs. } \\
/ 5 \text { Cm } \\
\text { step }\end{array}$ \\
\hline $\begin{array}{c}47-1 \mathrm{~A} \\
\text { panel }\end{array}$ & 1.91 & 12.3 & 35.5 & 9 & $300 *$ & $* *$ \\
\hline $\begin{array}{c}47-2 \mathrm{~A} \\
\text { Column }\end{array}$ & 1.72 & 9.1 & 33.5 & 15 & 400 & 2 \\
\hline $\begin{array}{c}47-2 \mathrm{~A} \\
\text { Column }\end{array}$ & 1.70 & 9.6 & 33.4 & 10 & 400 & 2 \\
\hline $\begin{array}{c}74-2 \mathrm{~A} \\
\text { Column }\end{array}$ & 1.70 & 9.4 & 30.5 & 15 & 400 & 2 \\
\hline
\end{tabular}

Comparison between Tables 20 and 21 shows that the specific gravities of the field mixed grouts were lower than those mixed in the laboratory. While some variations may be expected, the lower values indicate lower cement content of the field mixed grout. since all component were weighed before mixing the low specific gravities are attributed to settling of cementitious components. This was consistent with observations of solids settled on the bottom of the mixing containers. The grouts tend to settle despite the addition of bentonite, but mix uniformity would probably be improved with a high shear mixer. The flow times of the field mixed grouts were similar to those prepared in the laboratory. However, specific gravity is a better indicator of grout quality since it is directly related to the mix proportions.

For Mix 47-1A, the target grouting pressure was 400 bar, but only approximately 300 bar was reached. This was due to the relatively high viscosity of the grout and suggests that the mix may be unsuitable.. During withdrawal for the 47-1A panels the bit was twisted at angles of approximately 20 to $30^{\circ}$ four times per 5 $\mathrm{cm}$ step. The other grouts appeared to jet well and the withdrawal rate was varied to determine the effect on column diameter. In all cases large amounts of spoils were brought to the surface.

The flow rate of grouts $47-2 A$ and $74-2 A$ was estimated using the Casagrande flow charts for incompressible fluids and the known values of nozzle number and diameter and pressure. The charts are designed for cement-water mixes and require knowledge of water/cement ratio. Since the tested grouts contained superplasticizers, the w/c ratio that would give the equivalent viscosity to that for a mix without any additives was used in the estimations. The estimated flow rate for the grouts was $84 \mathrm{l} / \mathrm{min}$. From this flow rate the estimated volumes of grout injected per 
meter height of column are $4201 / \mathrm{m}$ and $2801 / \mathrm{m}$ for withdrawal rates of 15 and $10 \mathrm{~s} / 5 \mathrm{~cm}$ step, respectively $(20 \mathrm{~cm} / \mathrm{min}, 30 \mathrm{~cm} / \mathrm{min})$. The equivalent cementitious contents are $455 \mathrm{~kg} / \mathrm{m}$ and $303 \mathrm{~kg} / \mathrm{m}$ for $47-$ $2 \mathrm{~A}$ at withdrawal rates of 20 and $30 \mathrm{~cm} / \mathrm{min}$, respectively, and 449 $\mathrm{kg} / \mathrm{m}$ for $74-2 \mathrm{~A}$ at $20 \mathrm{~cm} / \mathrm{min}$.

From the jet grouting field trials it was obvious that future trials must require the use of proper grout mixing equipment, preferably a high shear mixer. It was also evident that a batch plant would expedite grout preparation. Bentonite would be better mixed separately and allowed to hydrate before adding grout constituents. Preparation of the water-bentonite mix in advance of grout mixing would also expedite the grouting operation. If slag modified mixes are desired for the barriers, Type Is cement would simplify batching of the dry ingredients. It may also be possible to substitute silica fume for bentonite as an additive to reduce settling of cement in the grout during mixing and storage. silica fume is easier to $\mathrm{mix}$ in grouts than bentonite, but more expensive and requires respiratory protection during handling. The correct amount of silica fume to reduce settling without detriment to the flow properties requires determination.

\subsection{IN-8ITU IMMOBILIZATION OF TRITIUM PLUMES}

A mobile plume of tritiated water (HTO) exists in the MWL. The reported activity of the plume in 1989 was 17,000 pCi/1 $\left(1.7 \times 10^{-8} \mathrm{Ci} / 1\right)$. The EPA 10 Code of Federal Regulations Part 20 gives maximum permissible activity in water above background levels of $3 \times 10^{-6} \mathrm{Ci} / 1$. Thus, the tritium in the landfill does not appear to pose a catastrophic threat. Tritium has a half life of 12.3 years. Immobilization of tritiated water can be achieved by different methods with varying degrees of success. The methods include adsorption by drying agents such as silica gel and immobilization in cementitious, coated and polymer impregnated cementitious materials. These methods have been reviewed (IAEA, 1981).

Fixation in cementitious materials is considered unsatisfactory for long term immobilization (IAEA, 1981; Wong, Khan and Guglielmi, 1984). Tritium exchanges for hydrogen in cement hydrates. The tritiated hydrate can, in turn, exchange for water that comes in contact with the fixed waste and thus be released. In this work, in-situ immobilization of the tritium plume with cementitious grouts was considered to have a low probability of long term success. Polymer grouts may be alternatives, but will have significantly higher costs.

Since the activity in the plume is relatively low and the half life is relatively short, use of barriers to contain tritium may be a more effective control than in-situ grout treatment. For these reasons, containment barriers were investigated in preference to 
immobilization with grout.

\subsection{IN-8ITU CONTAINMENT OF TRITIUN PLUME}

\subsection{Introduction}

The objective of the tritium subsurface containment barriers is to retard the transport of tritium so that decay to a nonhazardous activity occurs before reaching the groundwater at a depth of $150 \mathrm{~m}$. Complete containment of the plume by cementitious barriers was not expected nor aimed at since previous studies have demonstrated that tritium is not completely halted by these materials (Eicholz, Park and Hazin, 1989; Johnston and wilmot, 1992; Atkinson et al., 1990; Gause, 1983). It is assumed that subsurface barriers for tritium containment would be used in conjunction with a low permeability cap to prevent ingress of precipitation.

Two types of tritium containment barrier materials were evaluated. These were grouts for monolithic grout barriers and grouts for soil cement barriers. Sanded grout of the type similar to that studied for the CWL were used. The variations from Mix 70 were reduction of $\mathrm{w} / \mathrm{c}$ to reduce the amount of water that could exchange with tritium, cement type and mineral admixtures. Sulphate resistant (Types II and V) cement were substituted for Type $I$ in two of the grouts since these would give advantages if sulphates are present in the soil and also have reduced heat of hydration. Silica fume and blast furnace slag were investigated as partial replacements for Type I cement since these admixtures have been found to reduce the tritium diffusion coefficient (Johnston and Wilmot, 1992; Atkinson et al., 1990). The grouts used for soil cement barriers were slag modified with different w/C ratios (74-1 and 74-2).

\subsection{Experimental}

\section{2 .1 Materials}

Types I, II and $\mathrm{V}$ cement were used for the sanded grouts. Silica fume was used as a partial replacement for Type I cement at a level of $5 \%$ by weight. Grade 100 ground granulated blast furnace slag was used at a cement replacement level of $30 \%$ by weight in grout and 408 in soil cements. The same types of soil, bentonite, superplasticizer and sand as those used for the CWL barriers in Section 3 were used for the MWL materials. The mix proportions of the grouts are presented in Table 22. The type of cement is indicated. Coarse and fine grades of sand are also indicated. 
Table 22. Mix Proportions of Grouts for MWL Barriers

\begin{tabular}{|c|c|c|c|c|c|c|c|}
\hline Mix & $\begin{array}{c}\text { Cement } \\
\mathrm{kg} / \mathrm{m}^{3}\end{array}$ & $\begin{array}{c}\text { Slag } \\
\mathrm{kg} / \mathrm{m}^{3}\end{array}$ & $\begin{array}{c}\text { Silica } \\
\text { Fume } \\
\mathrm{kg} / \mathrm{m}^{3}\end{array}$ & $\begin{array}{c}\text { Sand } \\
\mathrm{kg} / \mathrm{m}^{3}\end{array}$ & $\begin{array}{c}\text { Water } \\
\mathrm{kg} / \mathrm{m}^{3}\end{array}$ & $\begin{array}{c}\text { Bentonite } \\
\mathrm{kg} / \mathrm{m}^{3}\end{array}$ & $\begin{array}{c}\mathrm{SP} \\
1 / \mathrm{m}^{3}\end{array}$ \\
\hline 81 & $\begin{array}{c}563 \\
(\mathrm{I})\end{array}$ & 241 & 0 & $\begin{array}{c}563(\mathrm{C}) \\
402(\mathrm{f})\end{array}$ & 362 & 18.0 & 16.1 \\
\hline 82 & $\begin{array}{c}819 \\
\text { (V) }\end{array}$ & 0 & 0 & $\begin{array}{c}573(\mathrm{C}) \\
410(\mathrm{f})\end{array}$ & 369 & 17.7 & 16.4 \\
\hline 83 & $\begin{array}{c}819 \\
(I I)\end{array}$ & 0 & 0 & $\begin{array}{c}573(\mathrm{C}) \\
410(\mathrm{f})\end{array}$ & 369 & 17.7 & 16.4 \\
\hline 84 & $\begin{array}{c}731 \\
\text { (I) }\end{array}$ & 0 & 81 & $\begin{array}{c}569(\mathrm{C}) \\
406(\mathrm{f})\end{array}$ & 365 & 7.2 & 16.2 \\
\hline $74-1$ & $\begin{array}{c}722 \\
\text { (I) }\end{array}$ & 481 & 0 & 0 & 577 & 10.9 & 24.1 \\
\hline $74-2$ & 556 & 370 & 0 & 0 & 667 & 13.0 & 18.5 \\
\hline
\end{tabular}

The mix proportions of the soil cements were the same as those for the $40 \%$ slag/60\% cement grout treated soil used for the CWL barriers. The mix proportions are repeated in Table 23 .

Table 23. Mix Proportions of MWL soil cement Barriers

\begin{tabular}{|c|c|c|c|c|c|c|}
\hline Mix & $\begin{array}{c}\text { Cement } \\
\left(\mathrm{kg} / \mathrm{m}^{3}\right)\end{array}$ & $\begin{array}{c}\text { Slag } \\
\left(\mathrm{kg} / \mathrm{m}^{3}\right)\end{array}$ & $\begin{array}{c}\text { Water } \\
\left(\mathrm{kg} / \mathrm{m}^{3}\right)\end{array}$ & $\begin{array}{c}\text { Bentonite } \\
\left(\mathrm{kg} / \mathrm{m}^{3}\right)\end{array}$ & $\begin{array}{c}\mathrm{sP} \\
\left(1 / \mathrm{m}^{3}\right)\end{array}$ & $\begin{array}{c}\text { Soil } \\
\left(\mathrm{kg} / \mathrm{m}^{3}\right)\end{array}$ \\
\hline $74 \mathrm{~S} 1$ & 490 & 326 & 391 & 6.5 & 16.3 & 816 \\
\hline $74 \mathrm{~S} 2$ & 322 & 215 & 388 & 7.7 & 10.7 & 1075 \\
\hline
\end{tabular}

\section{2 .2 Specimen Preparation}

The sanded grouts were mixed in a ChemGrout paddle mixer and used for flow time measurements and preparation of cylinder and beam specimens. The mixed grout was pumped by a piston displacement pump into the moulds. Soil cements were mixed in a planetary mixer using the same procedure as that in section 3.2.1. Discs for the tritium diffusion experiments discussed below were cut from $75 \mathrm{~mm}$ diameter cylinders and trimmed to fit the cell. 


\section{2 .3 Curing}

All specimens were cured in water to simplify experimental details and to ensure that tritium diffusion tests were performed on saturated discs. If the tritium diffusion specimens were cured by burying in soil, variations in moisture content would have been uncontrollable. Moisture variations would be detrimental since the mode of tritium transport of tritium depends on degree of saturation and reproducibility would be reduced. Also, tritium diffusion under saturated conditions represents a worst case.

Compressive strength cylinders were cured for 28 days and 84 days in water. Permeability coefficient cylinders and flexural strength beams were cured for 28 days. Tritium diffusion tests were performed on discs cured for 84 days.

\subsubsection{Unhardened Grout Properties}

The flow time of the sanded grouts was measured using an ASTM C 939 flow cone for which the efflux time of water is 8 secs. An ASTM fIOW cone was more appropriate than a Marsh funnel because of the higher viscosity and the presence of sand. Specific gravity was measured with a Baroid mud balance. Flow time and specific gravity of the grouts used for soil cement barriers (74-1 and 74-2) were measured during the work on stabilization of $\mathrm{Cr}$ and the results are presented in Tables 3 and 4 .

\subsubsection{Permeability Coefficient}

The procedure for measuring the water permeability coefficient of the grouts and soil cements is given in section 3.2 .5 and was the same as that for the CWL barriers. The applied pressure gradient was $207 \mathrm{kPa}$ and the confining pressure was $414 \mathrm{kPa}$. Permeability was measured before and after 12 wet-dry cycles to determine the resistance to permeable cracking.

\subsubsection{Unconfined Compressive Strength}

Compressive strength measurements were performed on the MWL barrier materials using the same method described in section 2.2.9.

\subsubsection{Wet-Dry Cycle Tests}

Wet-dry cycling was performed on the grout permeability cylinders. The cycles consisted of 5 hours submersion in water followed by 43 hours drying in air at relative humidity $40-50 \%$. Upon completion of the cycles the cylinders were saturated and retested for permeability. The same tests were performed on the 74S1 and 7452 soil cements as part of the CWL barrier studies.

\subsubsection{Flexural strength}

The sanded grouts were tested for flexural strength after 28 days wet curing. Six beams, $300 \mathrm{~mm} \times 50 \mathrm{~mm} \times 50 \mathrm{~mm}$, were cast and 
tested in third point loading as described in ASTM C 78.

\subsubsection{Tritium Diffusion Tests}

The diffusion of tritiated water through discs of grout and soil cement was studied and the effective diffusion coefficient calculated. Saturated conditions were used in order to simulate a worst case scenario. For saturated conditions the diffusion of tritium is thought to be controlled by permeability coefficient of the barrier material (Krasznai, 1993). Two grouts, 81 and 82 , and the soil cements $74 \mathrm{SI}$ and $74 \mathrm{S2}$ were chosen for study. Mix 84 was not tested because of high permeability coefficient and 83 was eliminated because it did not have any permeability advantages over 82 .

The diffusion cell used was the same type and dimensions as that for the chromium diffusion tests shown in Figure 11. The disc surfaces were in the "as cut" condition and were not polished. The thickness of the discs was $10-11 \mathrm{~mm}$ and was measured prior to cell assembly. Tritiated water was prepared by soaking cuo pellets contaminated with tritium in distilled water. The resultant tritiated water was analyzed by liquid scintillation counting and diluted to give an activity of $2.1 \times 10^{-8} \mathrm{Ci} / 1$. One side (active) of the diffusion cell contained $425 \mathrm{ml}$ of the tritiated water and the other side (non active) contained $425 \mathrm{ml}$ of distilled water. Samples of $1 \mathrm{ml}$ were withdrawn from the non-active side at periodic intervals for $\mathrm{H}-3$ analysis by liquid scintillation counting. The cell contents were stirred before sampling.

In order to minimize the generation of radioactive waste, and due to limited controlled area availability, only one disc of each mix was tested. Thus, caution must be used in making definite conclusions from the data, since any heterogeneities in the discs such as interconnected porosity may lead to high diffusion coefficients.

\subsection{Results and Discussion}

\subsubsection{Unhardened Grout Properties}

The ASTM flow times and specific gravities of the sanded grouts are given in Table 24. The results for Grouts 74-1 and 74-2 were presented in Table 3 and 4 .

The greatest flow time was measured for the grout containing slag and this is due to the fine particle size. The flow time of the silica fume mix (84) was lower than expected since silica fume typically makes grouts more viscous. However, Mix 84 had a lower bentonite content than 82 and 83 and this may explain the lower flow time. The ASTM flow cone is usually used for grouts with flow times less than 30 secs. All of the grouts were pourable and 
easily pumped.

Table 24. Unhardened Grout Properties for MWL Barriers

\begin{tabular}{|c|c|c|}
\hline Mix & ASTM Flow Time (s) & Specific Gravity \\
\hline 81 & 68.0 & 2.17 \\
\hline 82 & 40.4 & 2.21 \\
\hline 83 & 40.6 & 2.21 \\
\hline 84 & 33.6 & 2.18 \\
\hline
\end{tabular}

\subsubsection{Permeability Coefficient}

The results of the permeability coefficient measurements on the sanded grouts before and after wet-dry cycles are presented in Table 25 and Figure 19. The permeabilities of $74 \mathrm{~S} 1$. and $74 \mathrm{~S} 2$ were given in Tables 14 and 15.

Table 25. Permeability coefficients Before and After wet-Dry Cycles for MWL Barrier Grouts

\begin{tabular}{|c|c|c|}
\hline Mix & $\begin{array}{c}\text { Initial Permeability } \\
\left(\times 10^{-10} \mathrm{~cm} / \mathrm{s}\right)\end{array}$ & $\begin{array}{c}\text { Final Permeability } \\
\left(\times 10^{-10} \mathrm{~cm} / \mathrm{s}\right)\end{array}$ \\
\hline 81 & $2.2 \pm 0.5$ & $15 \pm 5$ \\
\hline 82 & $1.7 \pm 0.3$ & $12 \pm 3$ \\
\hline 83 & $2.2 \pm 0.6$ & $11 \pm 3$ \\
\hline 84 & $3.3 \pm 1.0$ & $5.7 \pm 0.7$ \\
\hline
\end{tabular}

The initial permeability coefficient data show that the slag modified mix (81) and the sulphate resistant mixes ( 82 and 83 ) have similar values. The permeability of the silica fume modified mix was slightly higher, and had a greater coefficient of variation. The 28 day wet cured permeabilities of the grouts were similar to those for $74 \mathrm{~S} 1\left(1.7 \times 10^{-10} \mathrm{~cm} / \mathrm{s}\right)$ and $7452\left(3.0 \times 10^{-10} \mathrm{~cm} / \mathrm{s}\right)$.

The permeabilities of the microcracked cylinders showed that the mix with $30 \%$ slag/70\% cement (81) had the least resistance to formation of permeable cracks. Of the four grouts tested, the silica fume modified mix (84) showed the best performance after 12 wet-dry cycles. The results can be compared with those obtained for Grout 70 tested in FY 93 which had $w / C=0.5$. This grout had an initial 28 wet cured mean permeability of $6.0 \times 10^{-10} \mathrm{~cm} / \mathrm{s}$. After 12 wet-dry cycles the permeability of 70 was $1.4 \times 10^{-9} \mathrm{~cm} / \mathrm{s}$. Thus, 


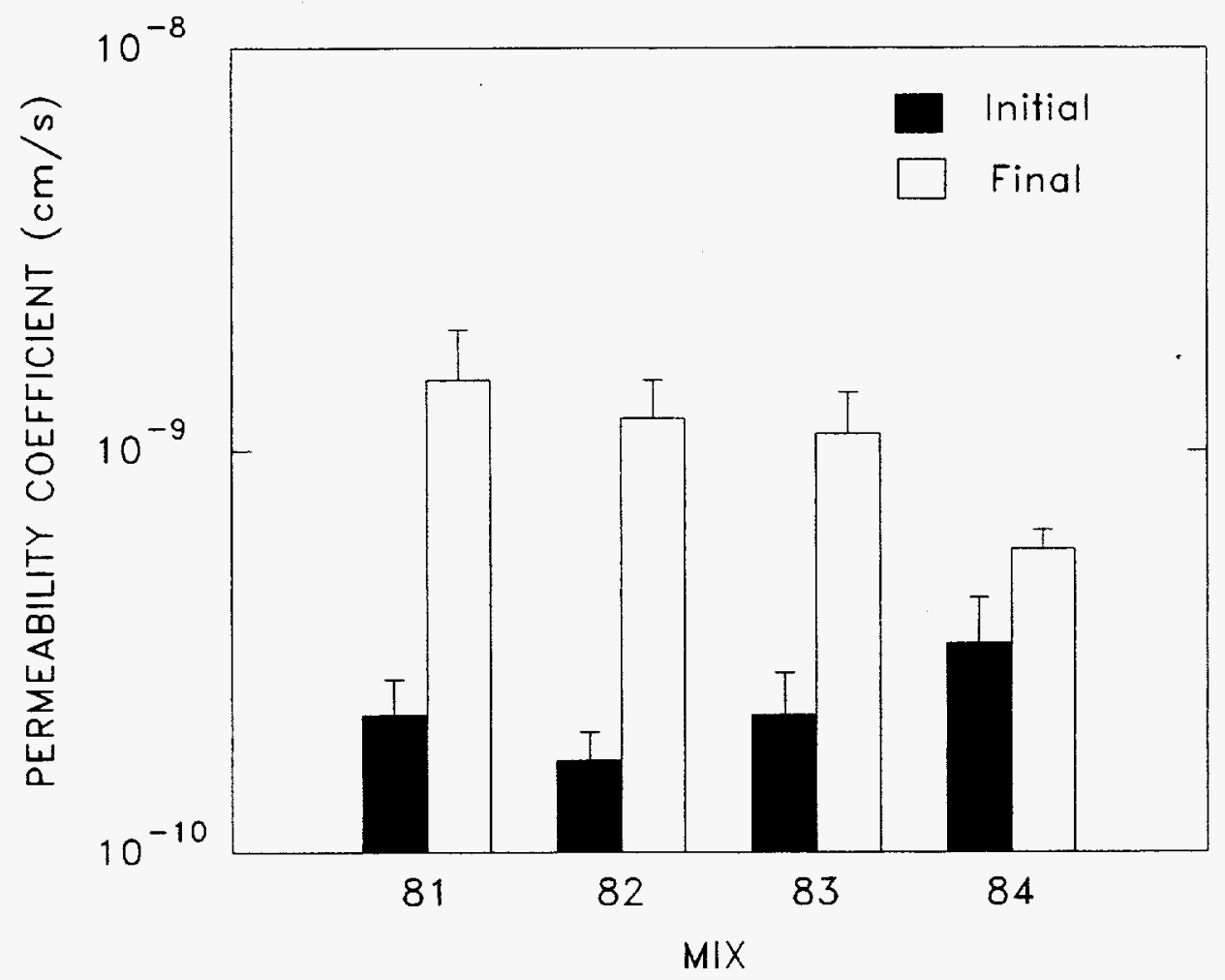

Figure 19. Permeability coefficients of wet cured grouts before and after 12 wet-dry cycles. 
the initial permeability is higher than that of any of the mixes in Table 25 due to the higher $w / C$ value, and the final value is similar to those for Grouts 81,82 and 83 .

\section{3 .3 Compressive strength}

The 28 day and 84 day wet cured compressive strengths of the sanded grouts are shown in Table 26 and Figure 20. The results for $74 S 1$ and 7452 are given in Table 18, section 3.3.5.

Table 26. Compressive strength of Mr Barrier Grouts

\begin{tabular}{|c|c|c||}
\hline Mix & $\begin{array}{c}28 \text { Day Compressive } \\
\text { strength (MPa) }\end{array}$ & $\begin{array}{c}84 \text { Day Compressive } \\
\text { Strength (MPa) }\end{array}$ \\
\hline 81 & $43.7 \pm 3.1$ & $43.3 \pm 1.2$ \\
\hline 82 & $53.2 \pm 2.7$ & $55.4 \pm 4.1$ \\
\hline 83 & $45.5 \pm 4.0$ & $45.0 \pm 3.1$ \\
\hline 84 & $34.3 \pm 3.3$ & $33.7 \pm 3.4$ \\
\hline
\end{tabular}

The Type $\mathrm{V}$ cement grout (82) had the highest strength and the slag modified (81) and Type II cement (83) grouts had similar strengths at both 28 and 84 days. The strength of the silica fume modified mix was lower than the others. This is possibly due to slow pozzolanic reaction, resulting in slow strength development. The grouts did not show significant strength gain between 28 and 84 days. This is possibly because the grouts were stored in water and leaching of calcium hydroxide may have occurred. If the grouts were stored in a fog room, or in a calcium hydroxide solution, a strength gain may occur. The compressive strengths are all well in excess of what is required for the grout barriers.

\subsubsection{Flexural strength}

Table 27 presents the 28 day flexural strength data for the sanded grouts. The results are also shown graphically in Figure 21.

The slag modified $\mathrm{mix}$ had the greatest flexural strength, and the silica fume modified mix the lowest. The Type II and $V$ cement grouts had similar strengths. The strengths are adequate for the barriers in all cases. 


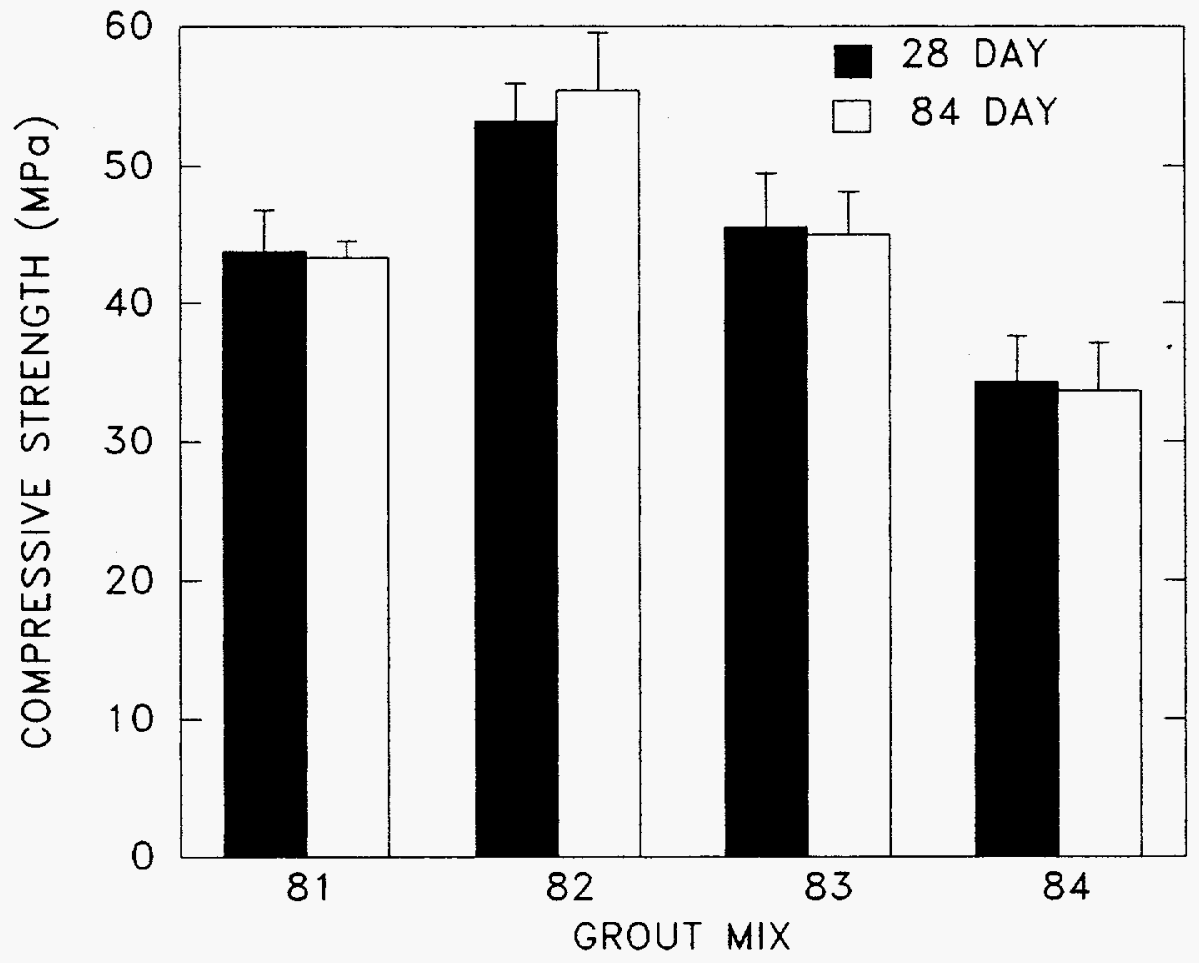

Figure 20. Compressive strength of grouts after 28 and 84 days wet curing. 


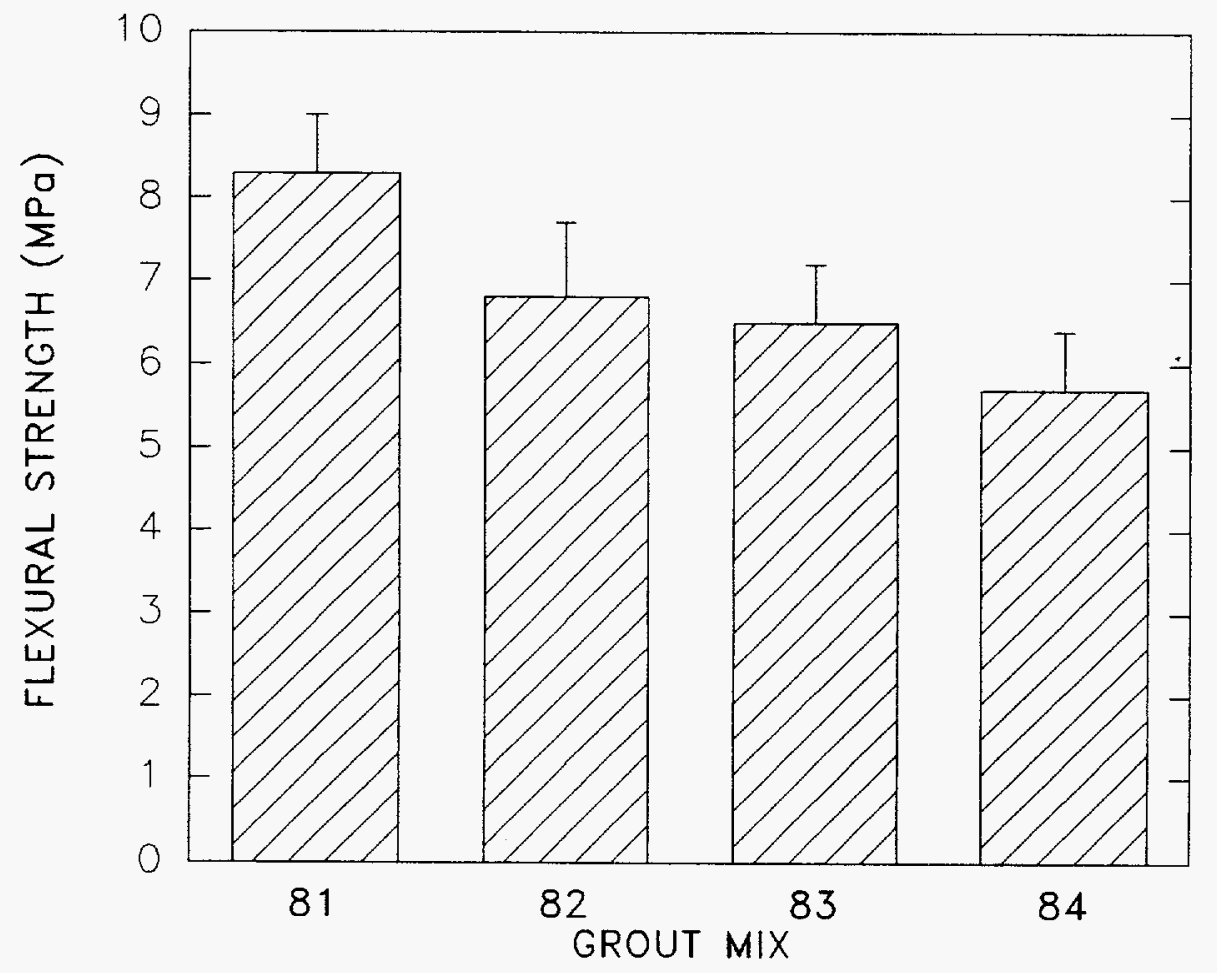

Figure 21. Flexural strength of grouts after 28 days wet curing. 
rable 27. Flexural strength of uwL Barrier Grouts

\begin{tabular}{|c|c|}
\hline Mix & Flexural Strength (MPa) \\
\hline 81 & $8.3 \pm 0.7$ \\
\hline 82 & $6.8 \pm 0.9$ \\
\hline 83 & $6.5 \pm 0.7$ \\
\hline 84 & $5.7 \pm 0.7$ \\
\hline
\end{tabular}

\subsubsection{Tritium Diffusion}

The activity of samples taken from the non-active side of the tritium diffusion cell was measured in disintegrations per minute. The intrinsic diffusion coefficient was calculated assuming Fick's first law of diffusion, steady state conditions and a linear concentration gradient within the disc. The boundary conditions were that the tritium activity in the non-active side was zero at time $=0$ and that the initial activity in the disc was also zero. Calculation of the intrinsic diffusion coefficient followed the procedure given by Atkinson and Nickerson (1984).

The intrinsic diffusion coefficient is defined by Equation 1.

$$
J_{x}=-D_{i} \frac{d c_{1}}{d x}
$$

where $J_{x}=f l u x$ of diffusant per unit area of porous medium

$D_{i}=$ intrinsic diffusion coefficient in porous medium

$c_{1}=$ activity in active side

$\mathbf{x}=$ position

In the initial stages of the diffusion process there is a transient period in which the porosity of the disc is filled with the tritiated water. After the transient period, steady state behaviour is reached where activity in the non-active side of the cell increases linearly with time. The intrinsic diffusion coefficient can be calculated once steady state is achieved from Equation 2 .

$$
D_{1}=\frac{I V}{A C_{1}} \frac{d C_{2}}{d t}
$$

where 1 = disc thickness (m)

$V=$ volume in non-active side $\left(\mathrm{m}^{3}\right)$ 
$A=$ disc cross-sectional area $\left(\mathrm{m}^{2}\right)$

$c_{1}=$ activity in active side (disintegrations per minute)

$c_{2}=$ activity in non-active side (disintegrations per minute)

$t=t i m e(s)$

Thus, the slope of a plot of $c_{2} I V / c_{1} A$ against time is the intrinsic diffusion coefficient. These plots for the four different materials are shown in Figure 22. Since samples were not taken in the first seven days, there are no data for the transient period. The values of intrinsic diffusion coefficient are given in Table 28.

Table 28. Intrinsic Diffusion Coefficients for Tritium

\begin{tabular}{|c|c|}
\hline Mix & $D_{i}\left(\mathrm{~m}^{2} / \mathrm{s}\right)$ \\
\hline 81 & $1.7 \times 10^{-10}$ \\
\hline 82 & $5.0 \times 10^{-11}$ \\
\hline $74 S 1$ & $1.4 \times 10^{-10}$ \\
\hline $74 S 2$ & $2.7 \times 10^{-11}$ \\
\hline
\end{tabular}

The results for the tritium diffusion tests show that the material with the highest permeability, porosity and w/C (74S2) had the lowest diffusion coefficient. The same mix also apparently had a longer transient time since the activity remained zero at 15 days, whereas the other materials showed transport of tritium by that time. The greater transient time is probably due to greater porosity and the associated time to fill that porosity with tritiated water.

The diffusion coefficients can be compared with other reported results for cementitious materials. Atkinson et al. (1990) measured intrinsic diffusion coefficients of $1.2 \times 10^{-11} \mathrm{~m}^{2} / \mathrm{s}$ for sulphate resistant mortar with $\mathrm{w} / \mathrm{c}=0.56$ and $5.6 \times 10^{-13} \mathrm{~m}^{2} / \mathrm{s}$ for mortar with $75 \% \mathrm{slag} / 25 \%$ cement and $\mathrm{w} / \mathrm{c}=0.56$. The mortars contained three parts sand to one part cementitious material by weight. These diffusion coefficients are lower than those measured on the grouts and soil cements. Johnston and wilmot (1992) reported tritium diffusion coefficients for neat plain and silica fume modified grouts with $\mathrm{w} / \mathrm{C}=0.25$ and 0.35 ranging from $4.8 \times 10^{-12}$ to $1.1 \times 10^{-11} \mathrm{~m}^{2} / \mathrm{s}$. These grouts were designed as sealants for underground nuclear waste repositories. Such low w/c values are not compatible with a pumpable sanded grout for barriers. 


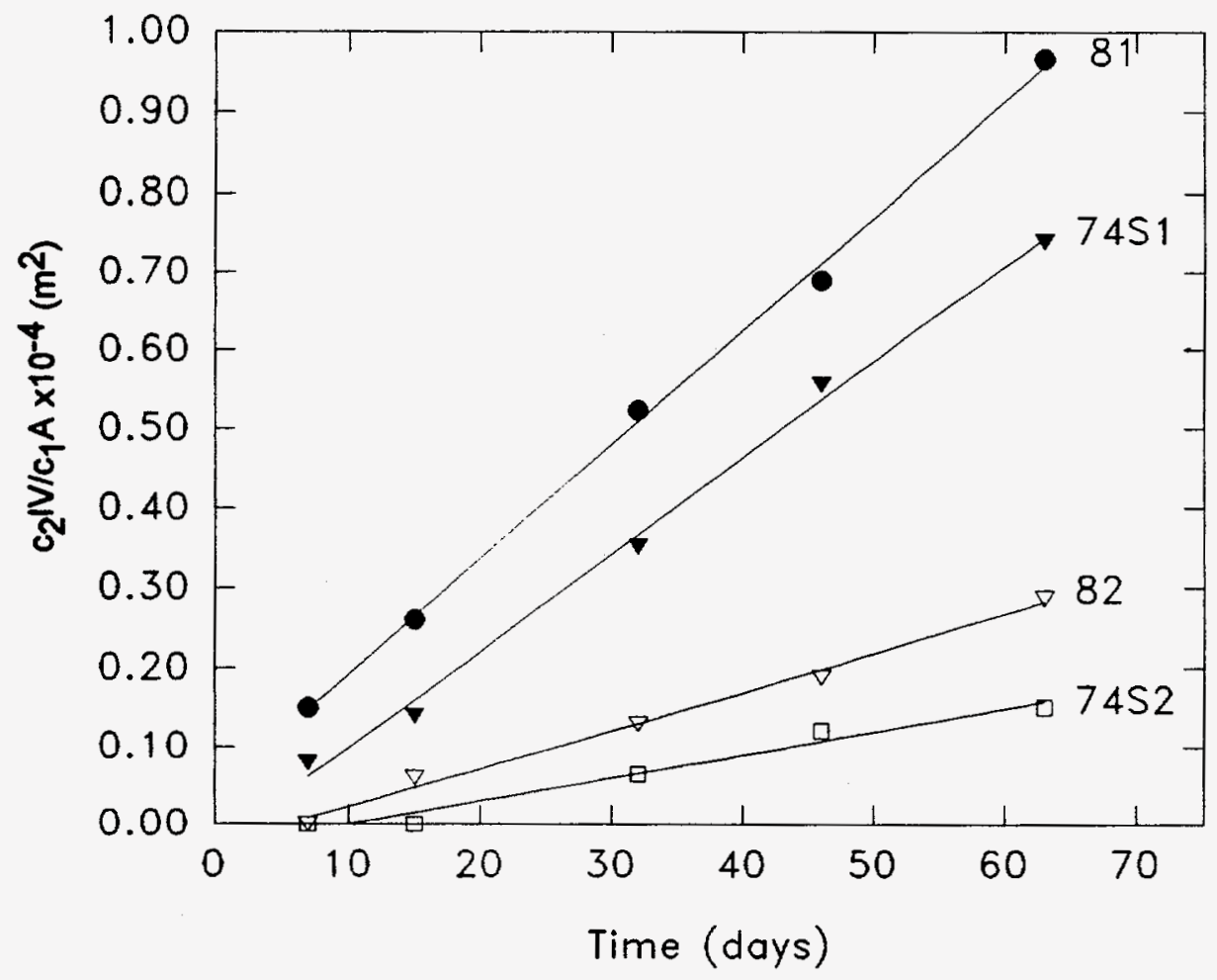

Figure 22. Tritium diffusion versus time for grouts and soil cements. 


\subsection{BITE VIBIT}

On 6 and 7 April, 1994 the Nicholson Construction of America site at Logan Airport, Boston was visited by BNL. The purpose of this visit was to view jet grouting and deep soil mixing and to discuss the possibility of collaboration. Nicholson construction is an experienced specialty geotechnical contractor with interests and capabilities in remediation using grouting technologies.

Jet grouting and soil mixing were being used at the site for large scale earth retention around rock anchors. The technologies being practiced are directly relevant to remediation of the CWL and MWL landfills. The jet grouting work was a joint venture between Nicholson and Rodio of Italy and the soil mixing was a joint venture between Nicholson and Seiko of Japan. The grout mixing plant and mixing procedure, $Q A / Q C$ measures and the jet grouting and soil mixing operations were observed. The parameters and capabilities of the two techniques were discussed with the site engineers and project managers.

Both jet grouting and soil mixing appear suitable grout placement techniques for the SNL landfills. Unlike permeation grouting, barriers can be placed exactly where required and continuity can be ensured by keying columns together. The techniques also permit control of the stabilized soil properties through variation of grouting parameters and materials. Dr. D.A. Bruce, Technical Director of Nicholson, suggested that jet grouting may be more economically favourable than soil mixing due to higher mobilization costs associated with movement of the soil mixing rig. The choice of equipment will also depend on the scale of the final remediation.

The equipment, operations and organization at the site were impressive and Nicholson expressed interest in the MWLID project. Observations made it clear that successful field demonstration and full scale remediation at SNL will require the skills of a competent and experienced grouting contractor since placement is a controlling factor in determining the quality of the final product. Incorrect or poor placement could result in an erroneous evaluation of both the grouting material and the placement technique. Therefore, it is imperative that a reputable contractor with a successful track record be used.

An invitation from Kent saugier of Halliburton NUS was received to view demonstration of the soilsaw ${ }^{\mathrm{TM}}$ barrier system at the DOE Savannah River site in February, 1994. Unfortunately, this could not be attended due to inadequate time to receive security clearance, compounded by inclement weather. Information regarding both the Savannah River demonstration and the Logan Airport activities were passed on to SNL. 
further field work using field scale mixing and grouting equipment. It is also desirable to evaluate use of Type Is cement in grout formulations since this is a blend of slag and cement and has the potential to simplify grout mixing.

Laboratory studies on hydraulic properties of subsurface barriers for the CWL show that low permeability can be retained for simulated soil curing conditions and after wet-dry cycling. Core samples from barriers placed during field demonstration of the jet grouting technique will be characterized. Further and more extensive field studies are required to optimize jet grouting parameters, such as pressure and withdrawal rate, and to refine the grout formulations so that the best performance can be achieved.

Diffusion coefficients for tritium were measured on four different MWL barrier materials. The coefficients were of the order of $10^{-11}$ to $10^{-10} \mathrm{~m}^{2} / \mathrm{s}$ and are similar to previously published values for grout and concrete.

Future work will test barrier materials in unsaturated conditions to give an improved representation of the behaviour in arid subsurface conditions. The resistance of grout stabilized soil and barrier materials to attack by sulphate ions will also be examined to ensure durability.

\subsection{REFERENCEB}

1. Allan, M.L., Kukacka, L.E. and Heiser, J.H. In-Situ Containment and Stabilization of Buried Waste, FY 92 Annual Report, BNL-48252, Brookhaven National Laboratory, Upton, New York (1993)

2. Allan, M.L. and Kukacka, L.E., In-Situ containment and Stabilization of Buried Waste, FY 93 Annual Report, BNL-49709, Brookhaven National Laboratory, Upton, New York (1993).

3. Atkinson, A., Claisse, P.A., Harris, A.W., and Nickerson, A.K. . Mass Transfer in Water-Saturated Concretes, in Scientific Basis for Nuclear Waste Management XIII, Oversby, V.M and Brown, P.W., Eds., Materials Research Society Vol. 176,741-748 (1990).

4. Atkinson, A. and Nickerson, A.K., The Diffusion of Ions Through water-Saturated Cement, J. Mat. Sci., Vol. 19, 3068-3078 (1984)

5. Biczok, I., Concrete Corrosion-Concrete Protection, Akademiai Kiado, Budapest (1972).

6. Connor, J.R. Chemical Fixation and Solidification of Hazardous Wastes, Van Nostrand Reinhold, New York. (1990).

7. Daniel, D.E., Anderson, D.C. and Boynton, S.S., Fixed-Wa 11 
Versus Flexible-Wall Permeameters, in Hydraulic Barriers in soil and Rock, ASTM STP 874, Johnson, A.I., Frobel, R.K., Cavalli, N.J. and Pettersson, C.B. Eds, American society for Testing and Materials, Philadelphia, 107-126 (1985).

8. Eichholz, G.G., Park, W.J and Hazin, C.A., Tritium Penetration Through Concrete, Waste Management, Vol. 9, 27-36 (1989).

9. Houlsby, A.C., Construction and Design of Cement Grouting, J. wiley and Sons, New York (1990).

10. International Atomic Energy Agency, Handling of TritiumBearing Wastes, Technical Report Series No. 203 (1981).

11. Ivey, D.G., Heimann, R.B., Neuwirth, N., Shumborski, S., Conrad, D., Mikula, R.J. and Lam, W.W. Electron Microscopy of Heavy Metal Waste in Cement Matrices. J. Mat. Sci., Vol 25, 5055-5062 (1990).

12. Johnston, H.M and Wilmot, D.J., Sorption and Diffusion studies in Cementitious Grouts, Waste Management, Vol. 12, 282-297 (1992).

13. Kindness, A., Macias, A., and Glasser, F.P. Immobilization of Chromium in cement Matrices, waste Management, Vol. 14, 3-11 (1994).

14. Krasznai, J.P., The Radiochemical Characterization of Regularand High-Density Concrete from a Decommissioned Reactor, Waste Management, Vol. 13, 131-140 (1993).

15. Langton, C.A. Metal Toxicity Evaluation of Savannah River Plant Saltstone Comparison of EP and TCLP Results. In: Waste Management ' 88 Proceedings, pp. 197-203, R.G. Post, ed. (1988).

16. Langton, C.A. and Wong, P.B. Properties of Slag Concrete for Low-Level waste Containment. In: Nuclear waste Management IV, Ceramic Transactions, Vol 23, pp. 191-199, G.G. Wicks, D.F. Bickford and L.R. Bunnell, eds. (1991).

17. Macphee, D.E. and Glasser, F.P. Immobilization Science of Cement systems. Mat. Res. Soc. Bull., XVIII, 66-71 (1993).

18. Mollah, M.Y.A., Tsai, Y-N, Hess, T.R. and cocke, D.I. An FTIR, SEM and EDS Investigation of Solidification/stabilization of Chromium Using Portland Cement Type V and Type IP. J. Haz. Mat. Vol. 30, 273-283 (1992).

19. Walton, J.C. and Seitz, R.R., Fluid Flow Through Fractures in Below Ground Concrete Vaults, Waste Management, Vol, 12, 179-187 (1992).

20. Wong, K.Y., Khan, T.A., and Guglielmi, F., Canadian Tritium 
Experience, Canadian Fuels Technology Project (1984)

21. Zamorani, E., Sheikh, I.A. and Serrini, G. Physical Properties Measurements and Leaching Behaviour of Chromium Compounds

Solidified in a Cement Matrix. Waste Management, Vol.8, 239-245 (1988). 